\title{
Structure and evolution of the East Sierran thrust system, east central California
}

\author{
George C. Dunne \\ Department of Geological Sciences, California State University Northridge, Northridge, California, USA
}

\section{J. Douglas Walker}

Department of Geology, University of Kansas, Lawrence, Kansas, USA

Received 9 November 2002; revised 27 January 2004; accepted 6 April 2004; published 20 August 2004.

[1] A belt of arc-parallel, northeast vergent contractional deformation, the East Sierran thrust system (ESTS), crops out for $\sim 150 \mathrm{~km}$ along the east side of the Sierran continental margin arc. The ESTS is nowhere wider than $\sim 20 \mathrm{~km}$, and it accommodated an estimated minimum of $\sim 9.3 \mathrm{~km}$ of horizontal shortening. Remarkably, it experienced repeated episodes of broadly coaxial and coaxial-planar contractional deformation beginning prior to $188 \mathrm{Ma}$ and continuing past $140 \mathrm{Ma}$. We postulate that the ESTS resulted primarily from episodic underthrusting of the back arc lithosphere beneath the east edge of the Sierran arc, facilitated by a buttressing effect of the arc. As a result of this process, rocks along the east flank of the batholith, including the ESTS, were episodically shortened against the arc buttress. The ESTS experienced significant deformation during the Nevadan orogeny, indicating that contractional to transpressive deformation affiliated with this event affected the eastern wall rocks of the arc as well as its western wall rocks. INDEX TERMS: 8102 Tectonophysics: Continental contractional orogenic belts; 9609 Information Related to Geologic Time: Mesozoic; 8015 Structural Geology: Local crustal structure; 9350 Information Related to Geographic Region: North America; KEYWORDS: eastern California, Mesozoic, structure, Cordilleran, thrust system. Citation: Dunne, G. C., and J. D. Walker (2004), Structure and evolution of the East Sierran thrust system, east central California, Tectonics, 23, TC4012, doi:10.1029/2002TC001478.

\section{Introduction}

[2] The back arc region of the southwestern U.S. Cordillera was affected by episodic contractional deformation during Mesozoic and early Cenozoic time, and much of this deformation was concentrated in prominent zones such as the Sevier, Central Nevada, and Luning-Fencemaker fold-thrust belts (Figure 1). In this paper we describe a less well known contractional belt of distinctly different style called the East Sierran thrust system (ESTS) that evolved in

Copyright 2004 by the American Geophysical Union. 0278-7407/04/2002TC001478 east central California during the Mesozoic (Figure 1). In its type region between the Garlock fault and the southern Inyo Mountains, the ESTS tracks the approximate eastern margin of continuous granitic terrain of the Sierran arc. On the basis of mapping at scales mostly between 1:8,000 and 1:24,000 and on 26 new U-Pb dates of igneous rocks that interact with structures, we present an overview of the geometry, kinematics, and chronologic development of the ESTS. We then use these descriptive and chronologic data to assess (1) possible correlative structures to those of the ESTS north and south of its type region; (2) possible genetic links between magma emplacement in the arc and deformation in the ESTS; and (3) correlation of ESTS deformational events with those previously recognized in and west of the Sierran arc.

\section{Geology of the ESTS}

\subsection{Geologic Framework}

[3] Collinear segments of the ESTS that are exposed in individual ranges form a $\mathrm{N} 35^{\circ} \mathrm{W}$ trending, predominantly NE vergent contractional belt extending $\sim 150 \mathrm{~km}$ northward from the Garlock fault to the southern Inyo Mountains (Figures 2, 3, 4, and 5). A colored geologic map of the ESTS has been published elsewhere [Dunne, 2003). The ESTS has a maximum transverse width of $\sim 20 \mathrm{~km}$, as exposed in the southern Inyo Mountains and Alabama Hills, but is as narrow as $4 \mathrm{~km}$ in the central Argus Range. Where it is widest, the ESTS displays a deformational gradient with intensity being greatest in the southwestern part of the belt, adjacent to the Sierran batholith, and decreasing irregularly toward the northeast. Schematic cross sections across two representative areas of the ESTS illustrate these transverse characteristics (Figure 6).

[4] The northwest trending ESTS is imposed across diverse rock sequences and older structures, many of which trend northeast. Rock sequences include strata of the Paleozoic miogeocline, arranged in northeast trending facies and isopach belts [Stevens et al., 1997], early Mesozoic marine strata, and nonmarine Jurassic volcanic and epiclastic strata. Scattered plutons and dikes representing the eastern fringe of the Sierran magmatic arc interact with ESTS structures as well. In the southern Inyo Mountains and northern Darwin Plateau area, the ESTS developed across 


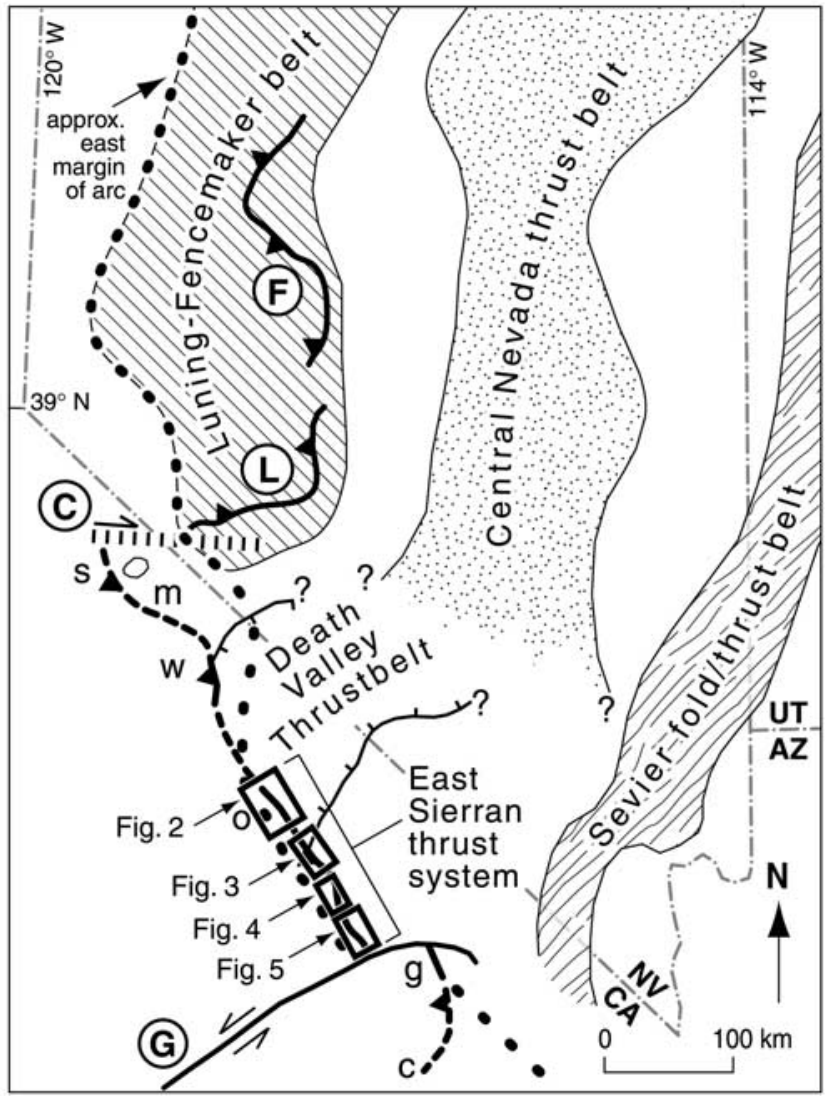

Figure 1. Major contractional belts in the southwest United States Cordillera east of the continental margin igneous arc. Patterned belts are of Mesozoic age and derived from Speed et al. [1988] and Taylor et al. [1993]. Death Valley belt is of Permian to Earliest Triassic age and derived from Taylor et al. [1993] and Snow [1992]. Approximate eastern edge of Sierran arc from Barton et al. [1988]. Key to geologic features marked by circled capitol letters: C, Coaldale-Excelsior fault zone; F, Fencemaker thrust; L, Luning thrust; G, Garlock fault. Other map locations are as follows: c, Cronese Hills; g, Granite Mountains; m, Mono Lake; o, Owens Lake; s, Saddlebag Lake; w, White Mountains.

thrust faults and folds of the Permian to earliest Triassic Death Valley thrust belt that were predominantly northeast trending and southeast vergent (Figure 1). Although structures of this older belt have been identified with confidence locally [Gulliver, 1976; Snow, 1992; Swanson, 1996; Stevens et al., 1997], there has yet to emerge a consensus as to where extended traces of these structures track across or along the ESTS [cf. Dunne, 1986; Corbett et al., 1988; Stevens et al., 1997].

\subsection{Characterization of the ESTS}

\subsubsection{Contractional Faults, Shear Zones}

[5] Northwest striking, predominantly northeast vergent contractional faults, fault zones, and shear zones are the most characteristic structures in the ESTS. Dips range from $\sim 10^{\circ} \mathrm{SW}$ in southern exposures to $\sim$ vertical in more northerly exposures of the southern Inyo Mountains (Figure 7). Characteristic dips in most subareas range between $50^{\circ}$ and $70^{\circ} \mathrm{SW}$.

[6] Along-strike variability of hanging wall and footwall rock units is a hallmark of ESTS contractional faults. Paleozoic and early Mesozoic strata, locally intruded by Mesozoic plutons, are predominant in the southern Inyo Mountains and northern Darwin Plateau. Paleozoic strata commonly display moderate to substantial stratigraphic differences from thrust plate to thrust plate [cf. Stone et al., 1989, Figures 2 and 3] resulting from the imposition of ESTS faults across varying NE trending facies. Plutons become increasingly abundant in both footwalls and hanging walls from the southern Darwin Hills to the Garlock fault. At several locations, footwalls of the structurally lowest thrusts are capped by upright Triassic and Jurassic strata that are widely preserved nowhere else in eastern California east of the Sierran batholith. Dunne and Walker [1993] argued that

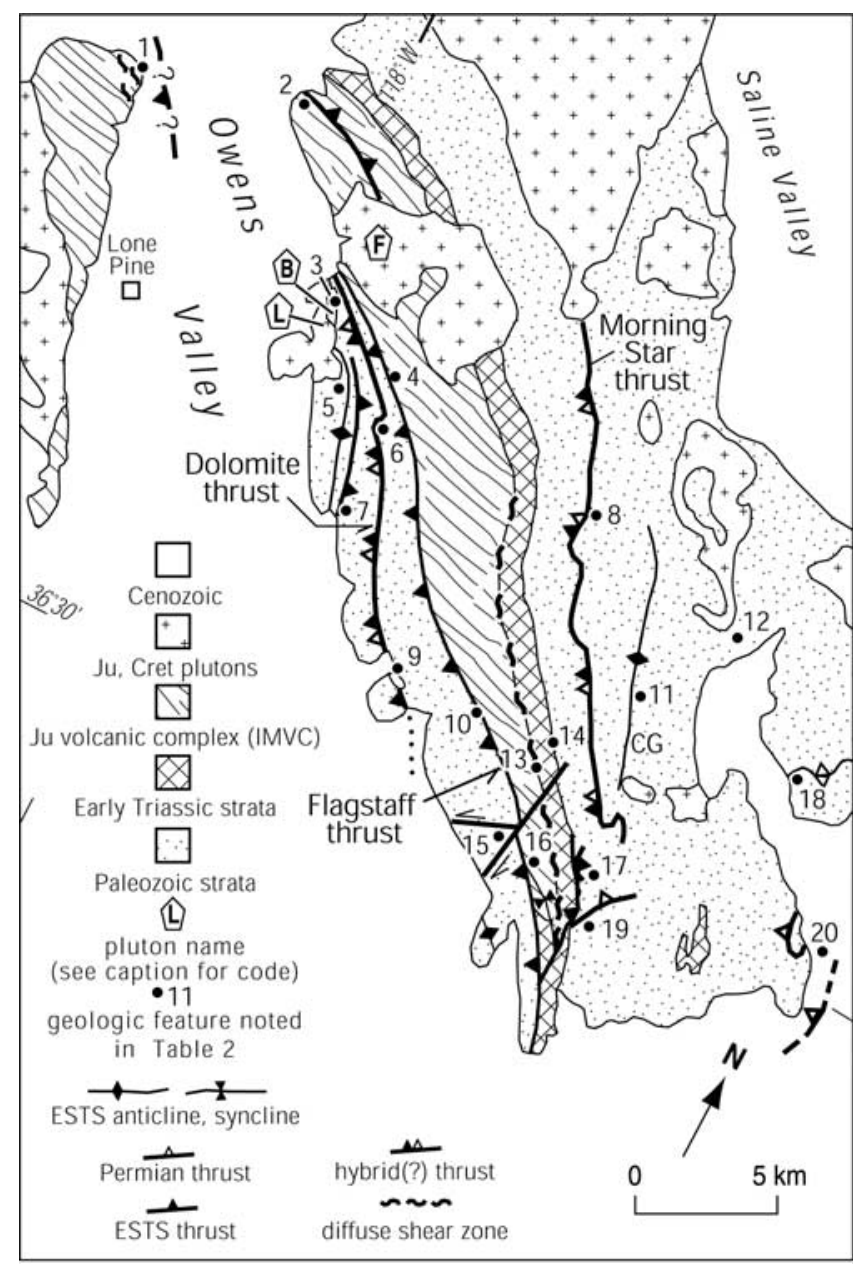

Figure 2. Geologic sketch map of the southern Inyo Mountains. IMVC is Inyo Mountains Volcanic Complex of Dunne et al. [1998]. Informal pluton names are as follows: F, French Spring; B, Black Warrior; L, Long John. 


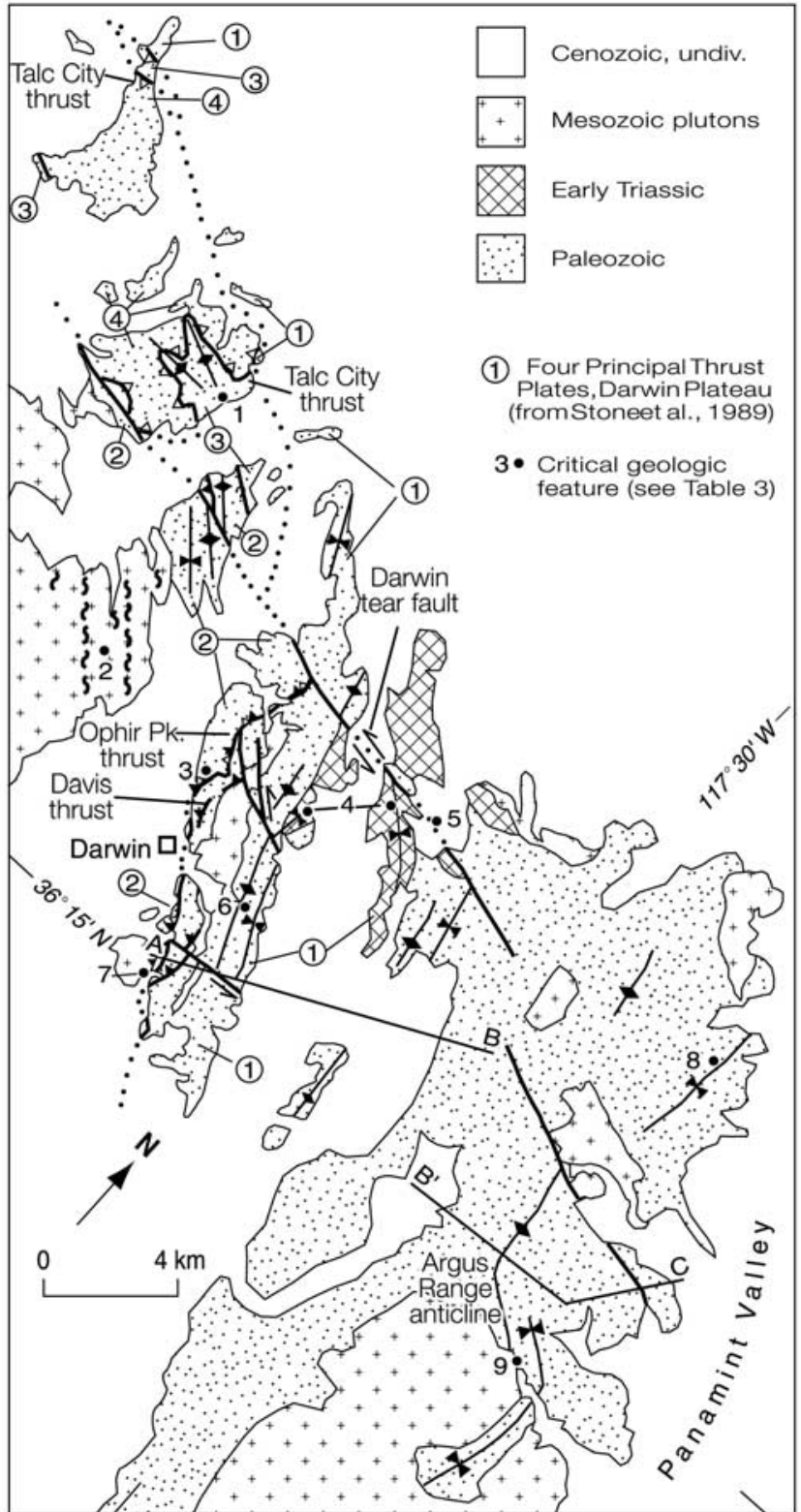

Figure 3. Geologic sketch map of the Darwin Plateau and northern Argus Range. Structural symbols are those of Figure 2.

this preferential preservation resulted from depression by and/or sheltering beneath thrust plates of the ESTS.

[7] Fault rocks adjacent to contractional faults range from cataclasites to mylonites. Mylonitic fault rocks derived from granitic protoliths typically display brittle/ductile to ductile fabrics formed under greenschist facies conditions and occupy zones as thick as $200 \mathrm{~m}$. Fault rocks derived from siliceous sedimentary rocks commonly are microbreccia and cataclasite restricted to within $1 \mathrm{~m}$ of the principal displacement surface, whereas those derived from limestone-rich protoliths are commonly ductilely transposed over zones as thick as $50 \mathrm{~m}$ (Figures $8 \mathrm{a}$ and $8 \mathrm{~b}$ ).
[8] Reverse-sense slip lines measured at 22 locations along the full length of the ESTS trend between WNW and SW, with an average trend of $S 71^{\circ} \mathrm{W}$ (Figure 7). A majority were determined by the Hansen [1971] method as applied to

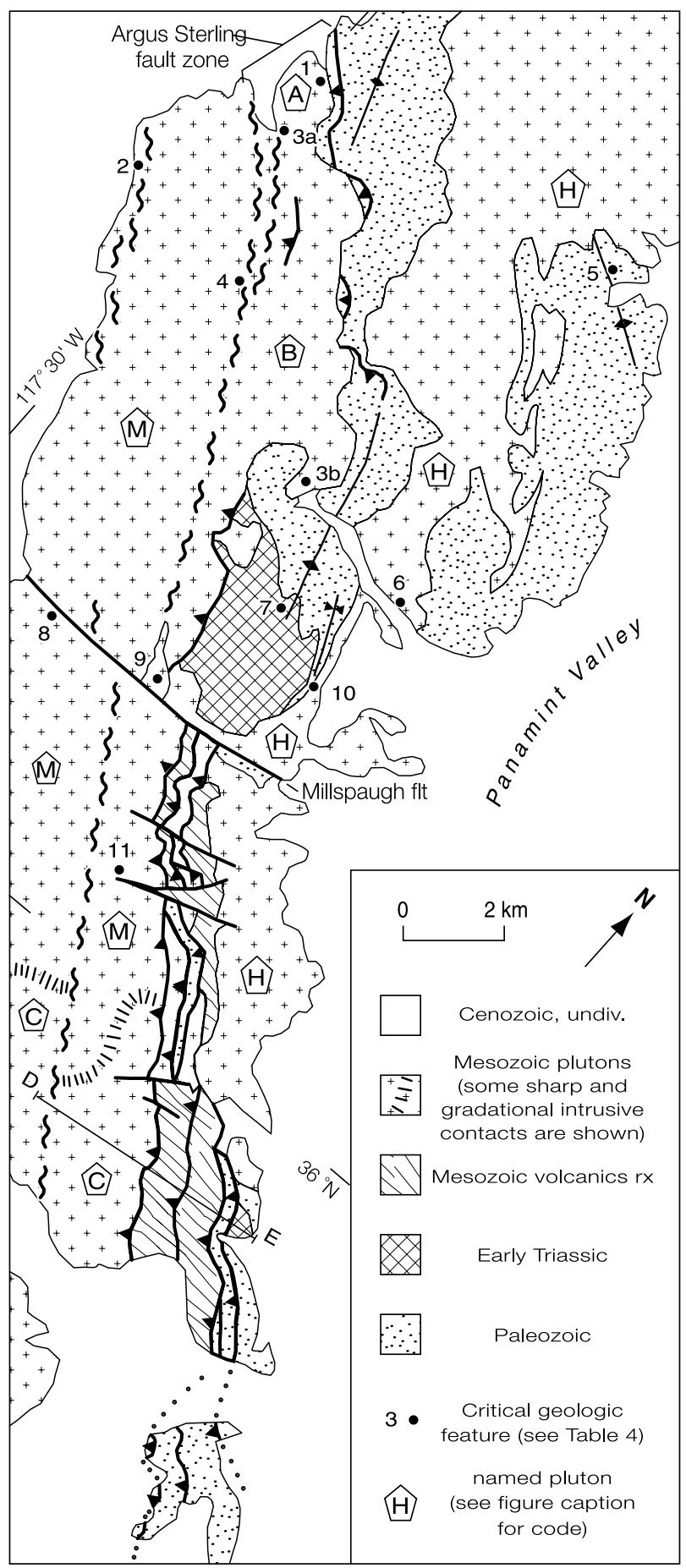

Figure 4. Geologic sketch map of the central Argus Range. Informal pluton names, simplified after those of Moore [1976], are as follows: A, Argus Sterling; B, Bendire Canyon; H, Hunter Mountain; M, Maturango Peak; C, Coso Range. Structural symbols follow those of Figure 2. 


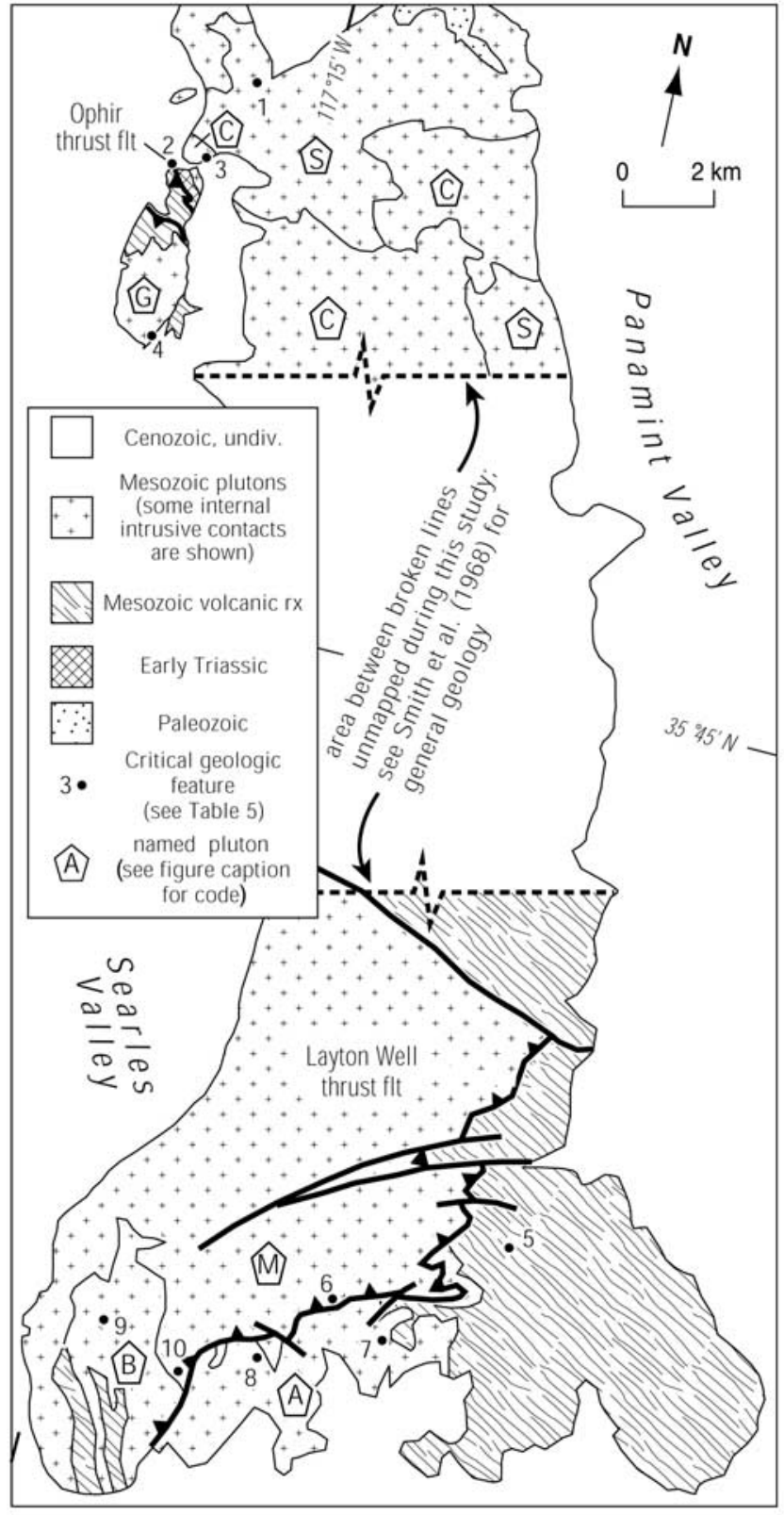

Figure 5. Geologic sketch map of the Slate Range. Structural symbols follow those of Figure 2. Simplified pluton names and contacts in northern area are from Moore [1976], as follows: S, Stockwell; C, Copper Queen; $\mathrm{G}$, Goldbottom. Informal pluton designations from southern area are as follows: A, Alaskite; B, Biotite Granite; M, Mixed Plutonic Complex.

small asymmetric folds in fault rock immediately adjacent to the thrust faults. Stretching lineations defined by pressure shadows, stretched pebbles and fossils, mineral streaks, and rods in these fault rocks are broadly parallel to the slip lines (Figure 8c). Where asymmetric thrust-generated folds are lacking, mean stretching lineations in fault rocks have been used as a proxy for slip line orientations.
[9] Meaningful estimates of minimum slip for ESTS contractional faults are difficult to derive because of (1) limited downdip fault exposures owing to their steep dips; (2) imposition of these faults onto diverse older structures and stratigraphic facies; and (3) wide tracts of plutonic rock that commonly compose much or all of one or both plates. Two faults with long traces for which minimum slip estimates can be made are the Layton Well thrust fault (Figure 5) in the southern Slate Range and the Flagstaff thrust fault (Figure 2) in the southern Inyo Mountains. We estimate that the former experienced a minimum slip of $10 \mathrm{~km}$ based on its preserved overlap and estimated minimum stratigraphic throw. Swanson [1996] estimated minimum slip of $\sim 3.9 \mathrm{~km}$ for the Flagstaff thrust fault.

[10] Although southwest dipping contractional faults characterize the ESTS, three northeast dipping, southwest vergent reverse faults have been mapped in the southern Inyo Mountains (Figure 2). These dip between $60^{\circ}$ and $80^{\circ} \mathrm{NE}$, can be traced laterally for only a few kilometers, and have geologic relations that are consistent with estimated slip amounts $<1 \mathrm{~km}$. We hypothesize that these faults represent minor backthrusts accommodating spatial adjustments within plates of the dominant northeast vergent structures.

\subsubsection{Folds and Associated Cleavage}

[11] Folds featuring north to northwest striking axial planes and affiliated axial plane cleavage are characteristic features of the ESTS and constitute at least two generations of folds that are approximately coaxial and coaxial planar. Typical folds are upright to slightly overturned to the northeast (Figure 8e), although folds inclined to the southwest are locally present in the southern Inyo Mountains and Argus Range (Figure 9). A distinct asymmetry is apparent in many overturned folds (Figure 9e). Folds in the southwestern, internal part of the ESTS tend to be tightest and show the greatest amount of bed thickening at fold hinges (Figure 8d). Folds of all sizes are present, with the largest having minimum half wavelengths of $\sim 4 \mathrm{~km}$ (cf. Figure 6). Plunge reversals from predominant northwest to subordinate southeast may reflect imposition of ESTS folds onto northeast trending, southeast vergent folds of the Death Valley thrust belt. An older, nearly bedding-parallel cleavage that locally developed within the Death Valley thrust belt is overprinted by ESTS folds in the Darwin Plateau area.

[12] Younger folds of diverse orientation and geometric character locally overprint typical ESTS folds and related cleavage in both the Darwin Plateau and southern Inyo Mountains. These folds tend to be developed in spatially restricted zones and for the most part lack axial cleavage. The most distinctive of these trend north to northwest and have southwest vergence, but most are upright and have axial trends ranging from oblique to perpendicular to the trend of the ESTS. All seem to have accommodated very small amounts of shortening. No meaningful younger age limit for these fold sets is available.

\subsubsection{Penetrative Strain}

[13] Rocks across the full width of the ESTS have been affected by variable amounts of penetrative strain. Evidence 


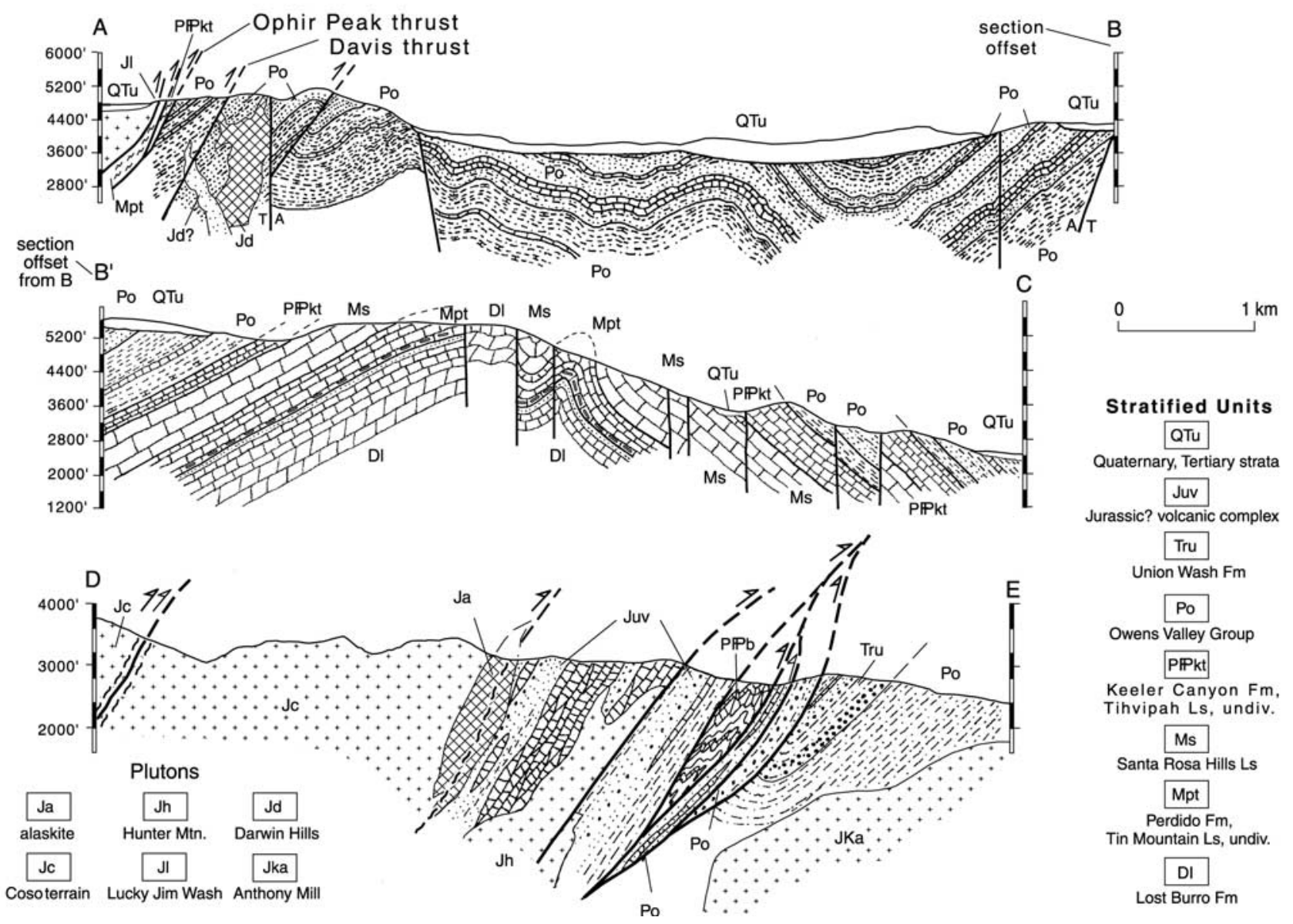

Figure 6. Geologic cross sections of the ESTS. Composite section A-B-C is representative of wider parts of the ESTS and is located in the southern Darwin Plateau and northern Argus Range (see Figure 3 for location). Modified from sections of Stone et al. [1989]. Section D-E is representative of narrower parts of the ESTS and is located in the central Argus Range (see Figure 4 for location). Includes data from Moore [1976].

of such strain includes axial plane cleavage, locally developed as two slightly oblique sets (Figure 8f); fibrous pressure fringes around pyrite; boudinage of beds and dikes, commonly in chocolate tablet style; and distorted pebbles, concretions, nodules, and fossils. We did not conduct a systematic study of strain, but a reconnaissance Rf/phi analyses of three conglomerate samples from the footwall of the Flagstaff thrust and of chocolate tablet boudins in beds in the hanging wall of this thrust (details presented in the auxiliary material ${ }^{1}$ ) did reveal the following insights. (1) All four analyses revealed that maximum extension (X), measured in the steeply dipping flattening planes (XY) that approximate cleavage in enclosing beds, ranges in amount from $45 \%$ to $85 \%$; $\mathrm{X}$ has a pitch of from $75^{\circ}$ to $90^{\circ}$ in the $\mathrm{XY}$ plane. (2) Y axes are within $15^{\circ}$ of horizontal and reflect $<7^{\circ}$ shortening or lengthening, thus revealing a roughly plane strain geometry. (3) Horizontal shortening, as derived

\footnotetext{
${ }^{1}$ Auxiliary material is available at $\mathrm{ftp} / / \mathrm{ftp}$. agu.org/apend/tc/ 2002 TC001478.
}

from the three conglomerate samples, averages $32 \%$. (4) The conglomerate sample collected closest $(\sim 10 \mathrm{~m})$ to the Flagstaff thrust experienced the greatest strain.

\subsubsection{Strike-Slip Fault Systems}

[14] Sets of strike-slip faults are prominent features on the west flank of the southern Inyo Mountains and to a lesser extent in the Darwin Plateau and northern Argus Range. Wherever observed, these faults cut all other contractional structures. In the southern Inyo Mountains, numerous strike-slip faults formed in two principal orientations, NNE (right slip) and ENE (left slip), with an average angle between faults of $55^{\circ}$ (Figure 10). Maximum observed slip on a fault in this system was $150 \mathrm{~m}$. We infer that these faults form a conjugate system based on their orientations in conjunction with their opposed slip senses and their mutually crosscutting junctions. Assuming equal amounts of slip on the two families of faults, this conjugate system accommodated a few percent of $\sim \mathrm{N} 45^{\circ} \mathrm{E}$ directed shortening. Northwest to west striking, steeply dipping leftstrike-slip faults in the Darwin Hills (Figure 3) may be 


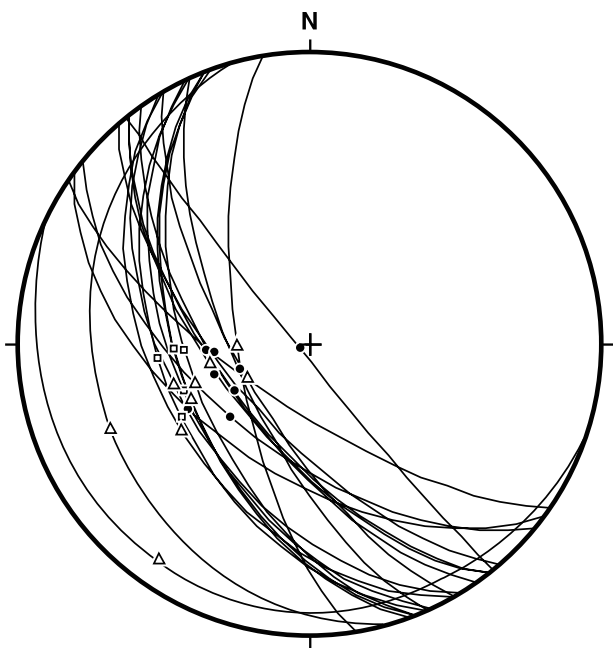

Thrust fault slip lines:

- Inyo Mountains

- Darwin Plateau

$\triangle$ Coso, Argus, Slate Ranges

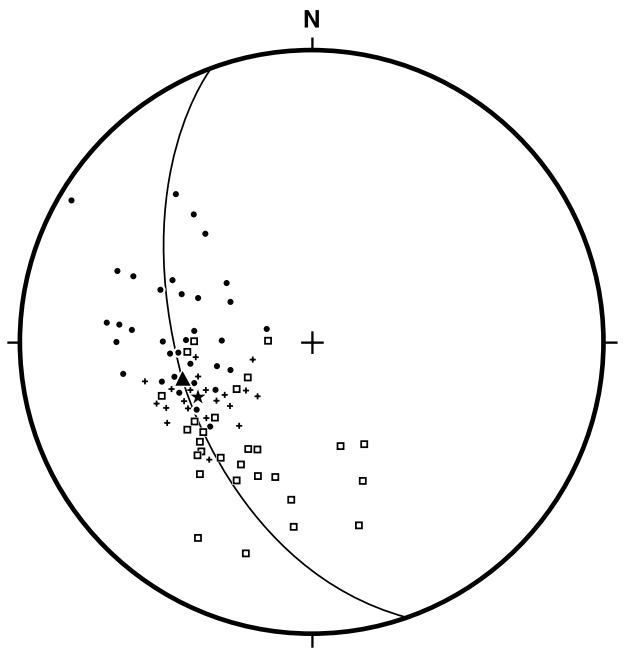

- clockwise fold axis $\quad \Delta$ inferred slip vector

- counter clockwise fold axis $\star$ mean stretching lineation - stretching lineation

Figure 7. (a) Summary stereogram (lower hemisphere, equal area) of representative contractional faults and related slip lines of the ESTS. (b) Representative Hansen diagram of thrust-generated asymmetric folds and associated stretching lineations for unnamed thrust in southern Darwin Hills. Symbols are as follows: bullet, clockwise fold axis; box, counterclockwise fold axis; plus, stretching lineation; solid triangle, inferred slip vector; star, mean stretching lineation.

correlative with the left-slip faults of the conjugate system in the southern Inyo Mountains.

\subsection{Estimated Shortening Across the ESTS}

[15] We estimate $\sim 9.3 \mathrm{~km}$ as the minimum amount of horizontal shortening by folding and contractional faulting across the ESTS in the southern Inyo Mountains, which, at a present day width of $18 \mathrm{~km}$, is the widest continuously exposed part of the belt, not including the Alabama Hills (Figure 2). This constitutes $\sim 34 \%$ shortening relative to the original width across this area. Shortening by folding contributed $\sim 5.6 \mathrm{~km}$ of the total, the remainder resulting from reverse slip on the Flagstaff thrust and three subsidiary faults. Using an average dip of $35^{\circ}$, the $3.9 \mathrm{~km}$ of minimum slip on the Flagstaff caused $\sim 3.2 \mathrm{~km}$ of shortening, and the three subsidiary faults with similar dips contributed an additional $\sim 0.5 \mathrm{~km}$ of shortening. Shortening that may have been contributed by the Dolomite Canyon and Morning Star thrusts was not included because of insufficient slip data. In the southern Slate Range, the Layton Well thrust is the principal contractional structure. The $\sim 10 \mathrm{~km}$ of minimum slip on this gently dipping $\left(10^{\circ}\right)$ fault accommodated a minimum of $\sim 8.8 \mathrm{~km}$ of horizontal shortening as measured perpendicular to the trend of the ESTS. Neither estimate of minimum shortening takes into account an additional component of shortening contributed by penetrative ductile strain, regarding which we have insufficient data on which to base a meaningful estimate.

\subsection{Chronology of Deformation in the ESTS}

[16] To supplement previously published studies that permitted a preliminary assessment of the temporal evolu- tion of the ESTS [Dunne and Walker, 1993; Dunne et al., 1998], we have determined 26 additional U-Pb dates for igneous units that interact with structures (Table 1 and Figures $11 \mathrm{a}-11 \mathrm{~d})$. The isotopic data for these radiometric analyses are available in the auxiliary material. Samples were analyzed using both conventional thermal ionization mass spectrometry (TIMS) and sensitive high-resolution ion microprobe (SHRIMP) techniques. TIMS work was done at the University of Kansas, and analytical procedures and instruments are the same as those described by Dunne et al. [1998]. SHRIMP work was done by M. Fanning and R. Van Schmus at the Australian National University using the SHRIMP II secondary ion mass spectrometer. Analytical procedures and instruments are described by Williams [1998] and Stern [1997].

\subsubsection{Comments on Age Methodology}

[17] Most of the ages reported in this paper were done by conventional U-Pb TIMS work on zircon over the period 1994 to 1999. Detailed descriptions of age interpretations as well as any problems in the age determinations are given in Table 1. One of the aspects of zircon isotopic behavior for similar rocks that we previously analyzed [Dunne and Walker, 1993; Dunne et al., 1998] as well as for many samples reported here is that despite significant air abrasion and other attempts to overcome the effects of $\mathrm{Pb}$ loss evident in the behavior of the zircon isotopic system, there is typically a spread of up to a few million years between the minimum age for a sample (based on the ${ }^{206} \mathrm{~Pb} /{ }^{238} \mathrm{U}$ ages of the oldest, most concordant fractions) and what these authors interpreted as the likely crystallization age (typically based on upper intercept ages or ${ }^{207} \mathrm{~Pb} /{ }^{206} \mathrm{~Pb}$ age spreads).

[18] In order to further assess this consistent pattern of age discrepancy, we reanalyzed three samples from this study, 


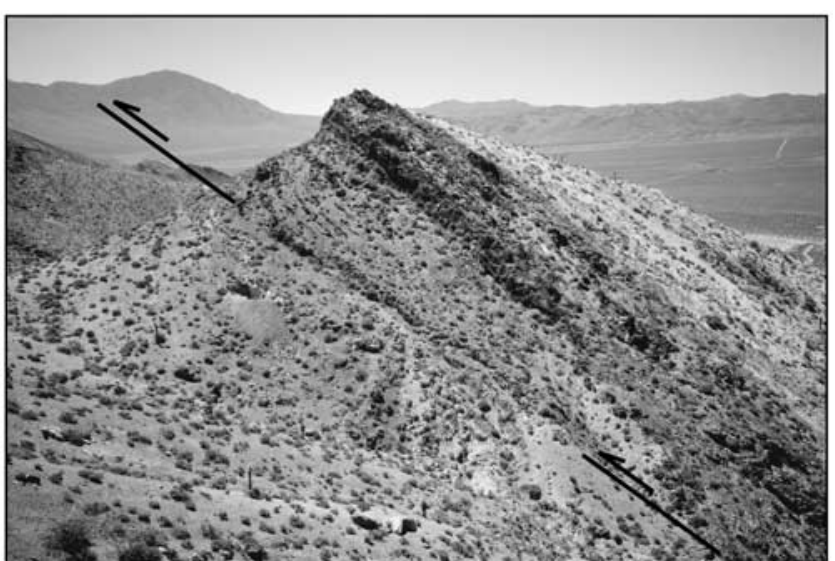

a

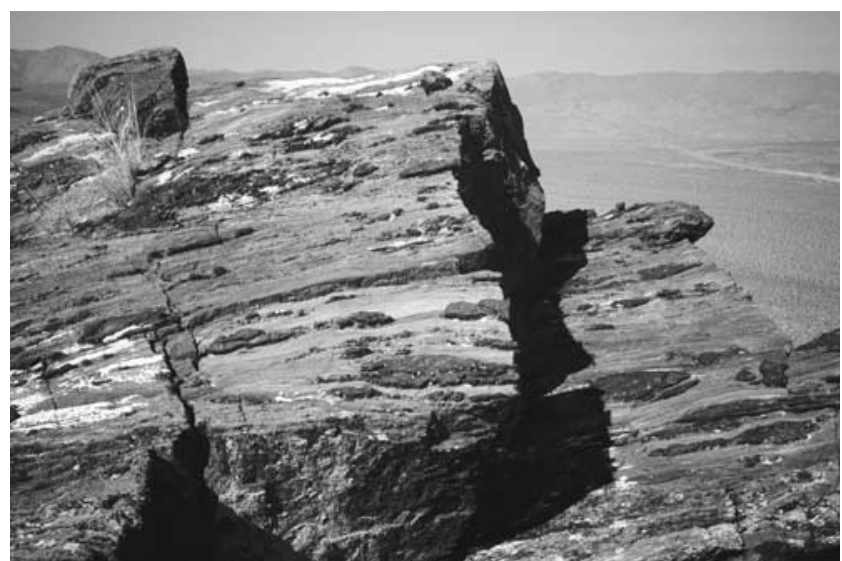

b

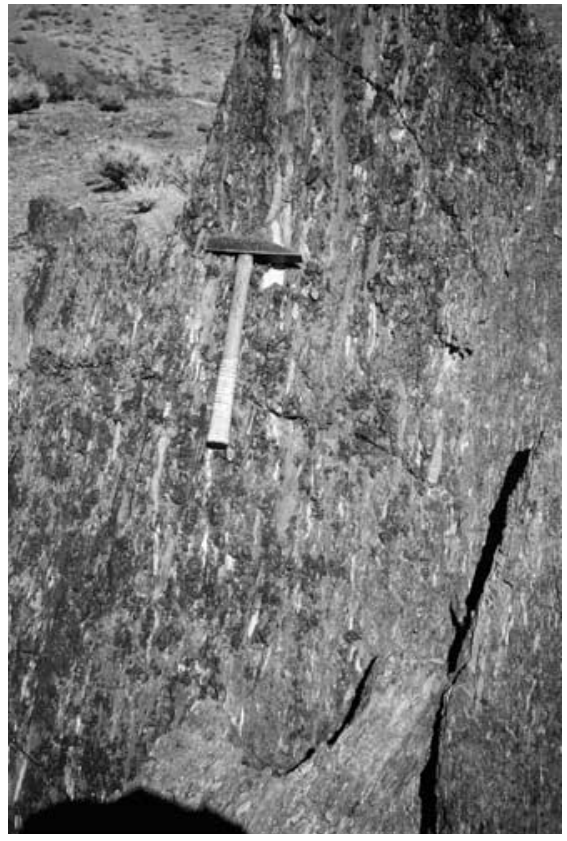

C

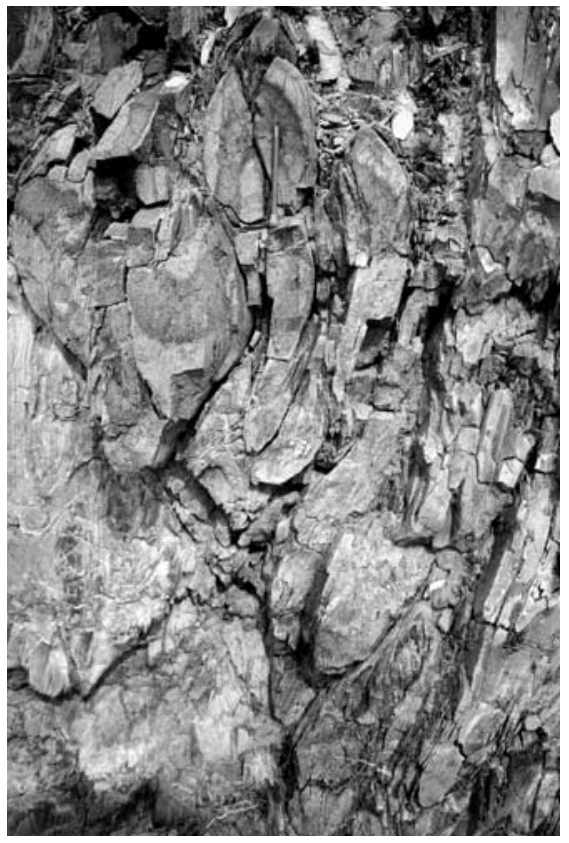

d

Figure 8. Outcrop photographs of selected structural features of the ESTS: (a) view SE along semibrittle thrust in southern Darwin Hills; (b) transposed cherty limestone a few meters above a ductile thrust in northern Darwin Hills; (c) stretched pebbles (parallel to hammer handle) in Jurassic conglomerate in footwall of Flagstaff thrust, southern Inyo Mountains; (d) isoclinal folds displaying moderate bed thickening at hinges, southern Inyo Mountains; (e) approximate profile view looking northwest at a large, asymmetric, east vergent syncline, southern Inyo Mountains; (f) steeply dipping bedding "b" overprinted by a penetrative axial plane cleavage "x" and a slightly oblique spaced cleavage "s." Photograph by Brian Swanson.

SR-35.2, SR-54.6, and SR-50.3, as well as one sample, SID3-94, described by Dunne et al. [1998] utilizing the SHRIMP analytical technique. In each case, the age determined from the SHRIMP technique is from $1 \%$ to $2.5 \%$ older than the conventional TIMS age (SR-35.2-149 Ma (TIMS) versus $151 \mathrm{Ma}$ (SHRIMP); SR-54.6-151 Ma (TIMS) versus $152 \mathrm{Ma}$ (SHRIMP); SR-50.3-149 Ma(TIMS) versus $153 \mathrm{Ma}$ (SHRIMP); and SI-D3-94-150 Ma (TIMS) versus $154 \mathrm{Ma}$ (SHRIMP); see also Table 1 and auxiliary material).

[19] On the basis of this consistent pattern of TIMS and SHRIMP ages, we conclude that (1) the age interpretations by TIMS presented in this paper are consistent with, although slightly younger than, ages determined by an independent technique; and (2) the ages presented in this paper, which are mostly considered minimum ages, are 


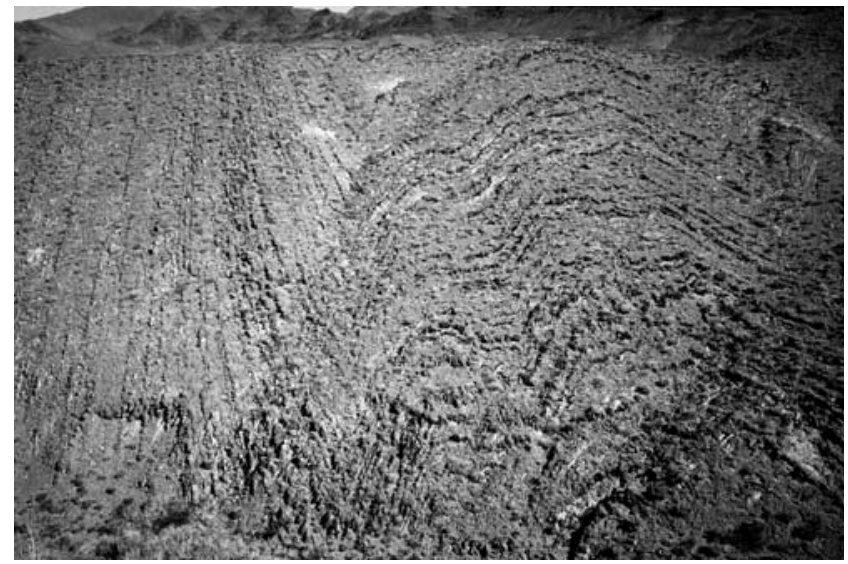

e

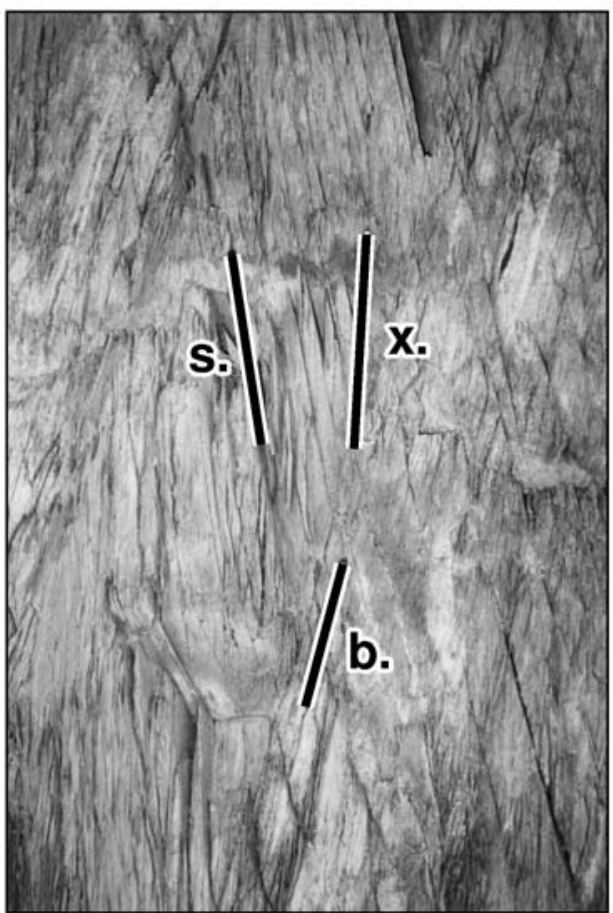

f

Figure 8. (continued)

probably within $\sim 2.5 \%$ of the likely crystallization ages. Moreover, we are confident that our TIMS ages are sufficiently accurate to allow recognition of events whose ages are separated by more than about 4 m.y., and to allow meaningful comparisons with rocks dated by others. We note, for example, that our TIMS U-Pb age for the Bendire pluton, $188 \pm 3 \mathrm{Ma}$, is, within error limits, the same as the TIMS U-Pb age of $185 \mathrm{Ma}$ determined for this same pluton by Chen and Moore [1982].

\subsubsection{Chronology of Deformation}

[20] Chronologic data, considered together with field relationships (Tables 2, 3, 4, and 5), reveal that the ESTS evolved episodically over a span at least 48 m.y. Dating of widespread early Middle Jurassic plutons and of late Late Jurassic volcanic and intrusive rocks that interact with structures allows informal temporal partitioning of episodes of deformation to enhance descriptive convenience. To this end, we recognize "early" (prior to early Middle Jurassic), "middle" (post early Middle Jurassic/prior to late Late Jurassic), and "late" (post late Late Jurassic) intervals (Figure 12).

[21] Deformation during the early interval apparently began after deposition of the Early and early Middle Triassic Union Wash Formation, based on the observations that (1) this formation has nowhere been observed to overlap ESTS-like structures and (2) prominent ESTS folds involving these strata are intruded and deformed by mid Middle Jurassic plutons in the Darwin Hills (Table 3, location 6) and Argus Range (Table 4, location 10). Other large ESTS folds predate middle Middle Jurassic plutons in the southern Inyo Mountains (Table 2, location 5) and northern Argus Range (Table 3, location 9). The oldest movement zone (east side) of the long-lived Argus Sterling thrust zone predates an early Middle Jurassic pluton (Table 4, locations 3a and 3b). In sum, widespread folding and some thrust faulting occurred in the ESTS following deposition of Early Triassic strata and prior to intrusion of plutons ranging in age from $\sim 173 \mathrm{Ma}$ to $\sim 188 \mathrm{Ma}$.

[22] Deformational events assigned with confidence to the middle interval of the ESTS postdate Late Jurassic volcanic strata ranging in age from $\sim 154 \mathrm{Ma}$ to $\sim 152 \mathrm{Ma}$, and are in part coeval with small plutons intruded in the southern Slate Range between $\sim 152 \mathrm{Ma}$ and $\sim 150 \mathrm{Ma}$. Much of the middle interval was marked by widespread deposition of Middle and Late Jurassic ( $>169$ Ma to $<152 \mathrm{Ma}$ ) volcanic and volcaniclastic strata interpreted by Dunne et al. [1998] to have accumulated in a relatively quiescent deformational environment. Near the end of the middle interval, these sections were tilted $>35^{\circ}$ southwest and subsequently folded and overrun by the Flagstaff thrust plate in the Inyo Mountains and Layton Well thrust plate in the Slate Range. Tilting and folding of the Inyo Mountains Jurassic section occurred between deposition of the youngest preserved strata $(<152 \mathrm{Ma})$ and before emplacement of Independence dikes $(\sim 148 \mathrm{Ma})$, which remain steeply dipping.

[23] Tilting of stratigraphic sections immediately prior to significant contractional events was a widespread phenomenon in and adjacent to the Sierran arc during Middle to Late Jurassic time [Hanson et al., 1996; Tobisch et al., 1989, 2000; Wolf and Saleeby, 1995]. However, whether these tilting events were of extensional origin, perhaps related to relatively brief episodes of transtensional plate boundary interactions [cf. Wolf and Saleeby, 1995] or were an early phase of the subsequently more ductile and penetrative contractional deformation that followed is uncertain. Although an extensional origin for ESTS tilting cannot be ruled out, no specific evidence observed in the study area favors it. We tend to favor a contractional origin for ESTS tilting, perhaps enhanced by wall rock downflow [cf. Tobisch et al., 2000] that may have accompanied the 
a.

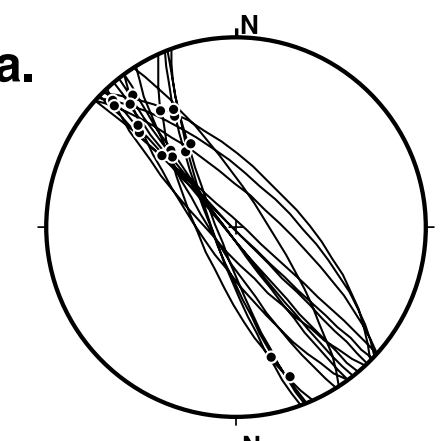

b.
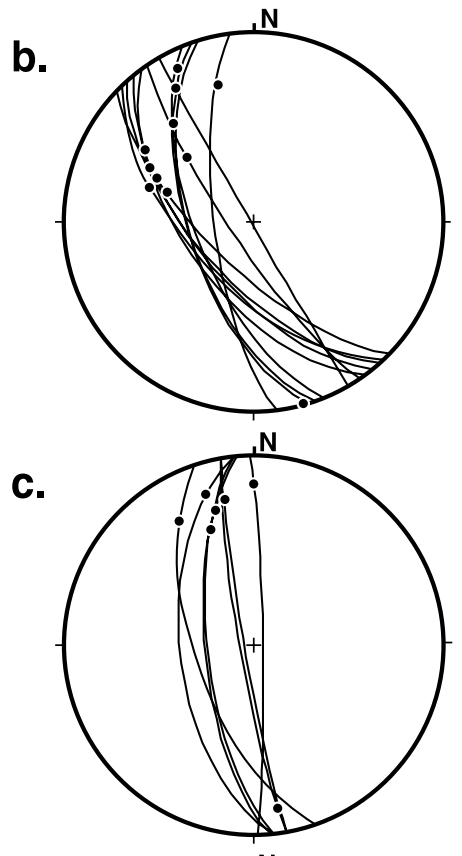

d.

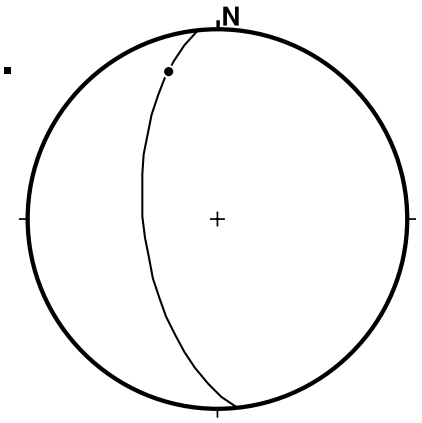

e.

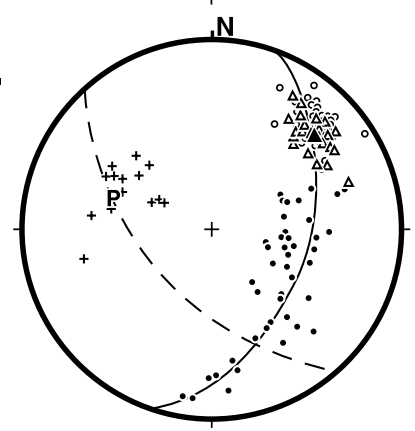

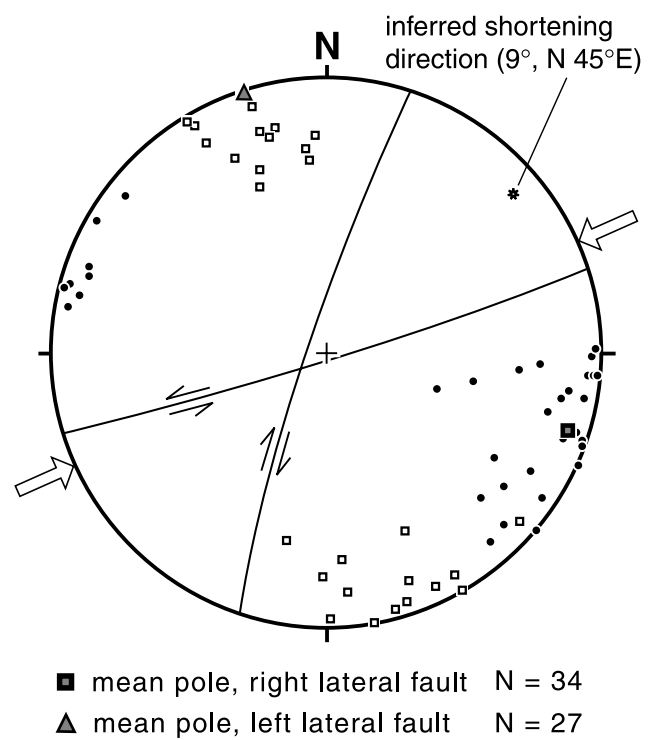

Figure 10. Stereogram (lower hemisphere, equal area) of conjugate strike-slip faults, southern Inyo Mountains. Indicated shortening direction assumes approximately equal slip accommodated on left- and right-slip fault systems. Opposed open arrows on perimeter of stereogram represent estimated mean shortening direction accommodated by thrust faulting and folding, as inferred from average value of thrust slip directions and normals to mapped traces of hinge planes of major folds.

modest pulse of Late Jurassic plutonism in the Sierran arc [Ducea, 2001].

[24] Dunne et al. [1998] presented arguments favoring the interpretation that the Flagstaff and Layton Well thrusting occurred soon after deposition of the youngest preserved rocks in footwalls of the Flagstaff and Layton Well thrusts ( $\sim 153$ Ma utilizing dating reported herein), and synchronous with or soon following SW tilting of these sections that occurred prior to emplacement of Independence dikes at $\sim 148$ Ma. Dating of $\sim 152$ Ma synkinematic plutons and deformed $\sim 151$ Ma plutons along the Layton Well thrust

Figure 9. Stereograms (lower hemisphere, equal area) of fold data for ESTS. Summary stereograms of axes and related axial planes of representative prominent folds and fold sets in the (a) southern Inyo Mountains, (b) Darwin Plateau, (c) Argus Range, and (d) Slate Range. Each plotted axial plane and axis summarizes between 15 and 95 data points from domains $>2 \mathrm{~km}^{2}$. (e) Stereogram of poles of bedding and cleavage and of minor fold hinge lines of a slightly northeastward overturned fold in the northern Darwin Hills; note profile asymmetry revealed by distribution patterns of upright and overturned beds and cleavage. Symbols are as follows: bullet, upright bed pole; circle, overturned bed pole; open triangle, axial cleavage pole; plus, parasitic fold axis; solid triangle, mean cleavage pole; dashed line, mean cleavage plane; P, pi-point. 


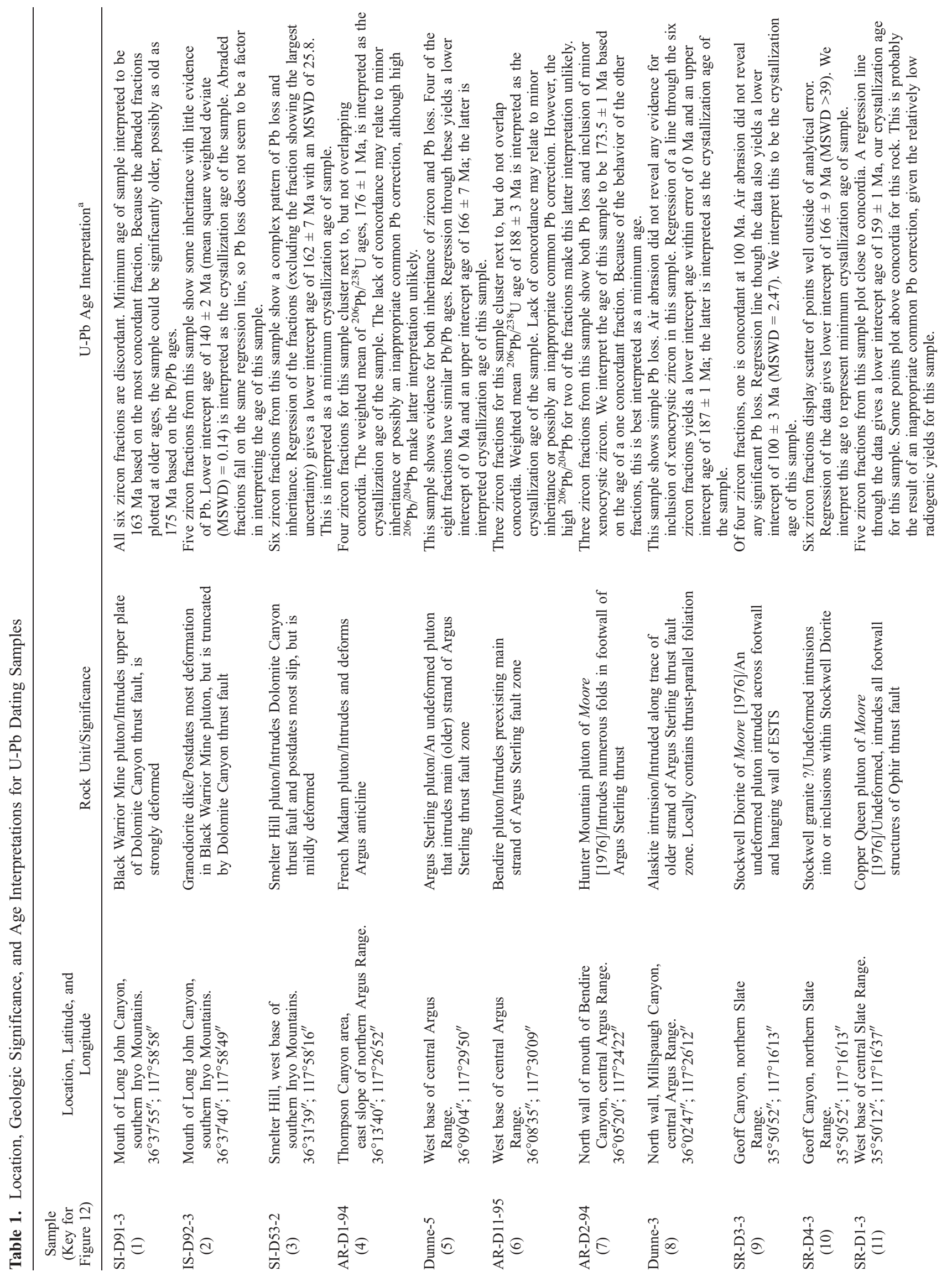




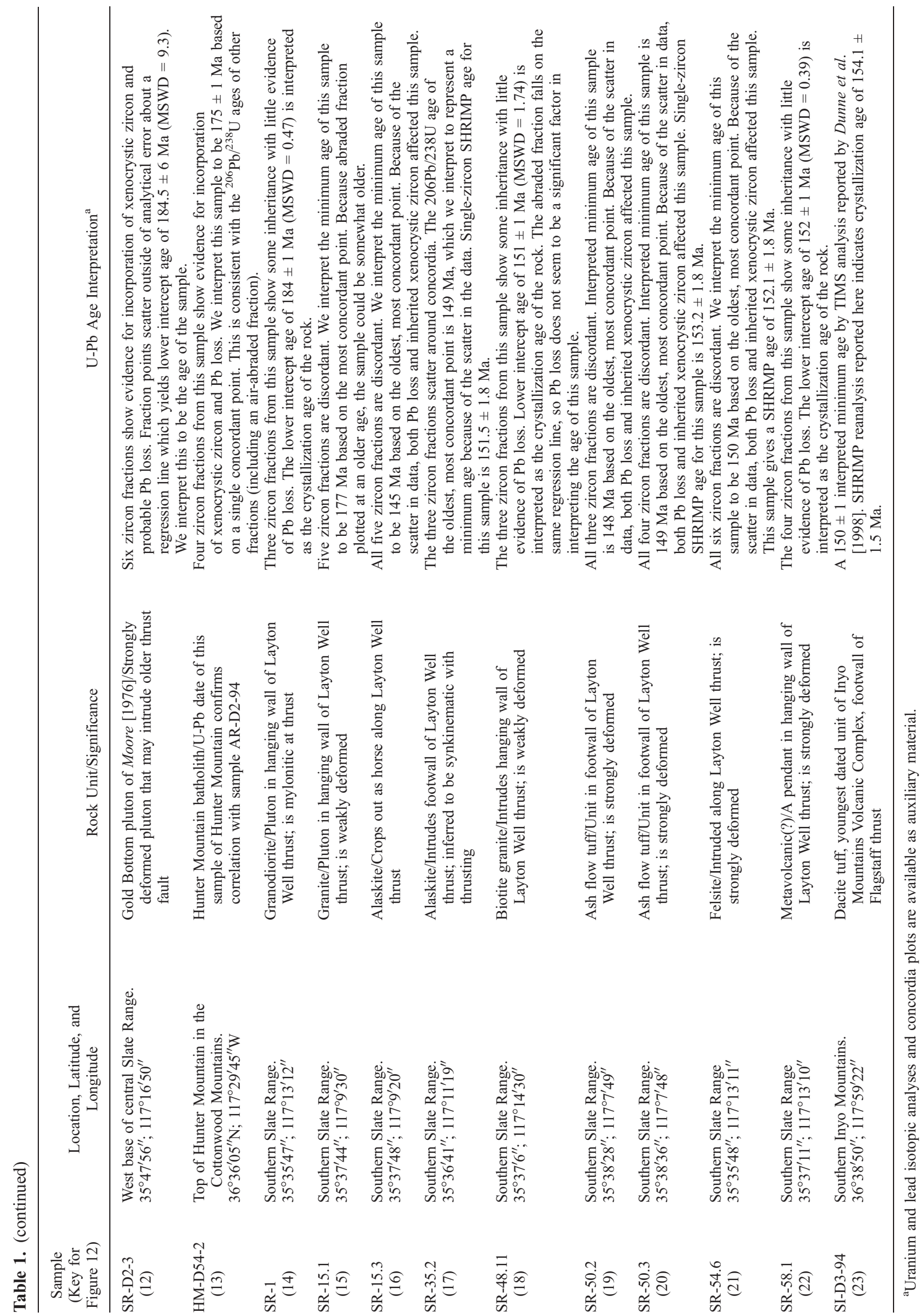


a)
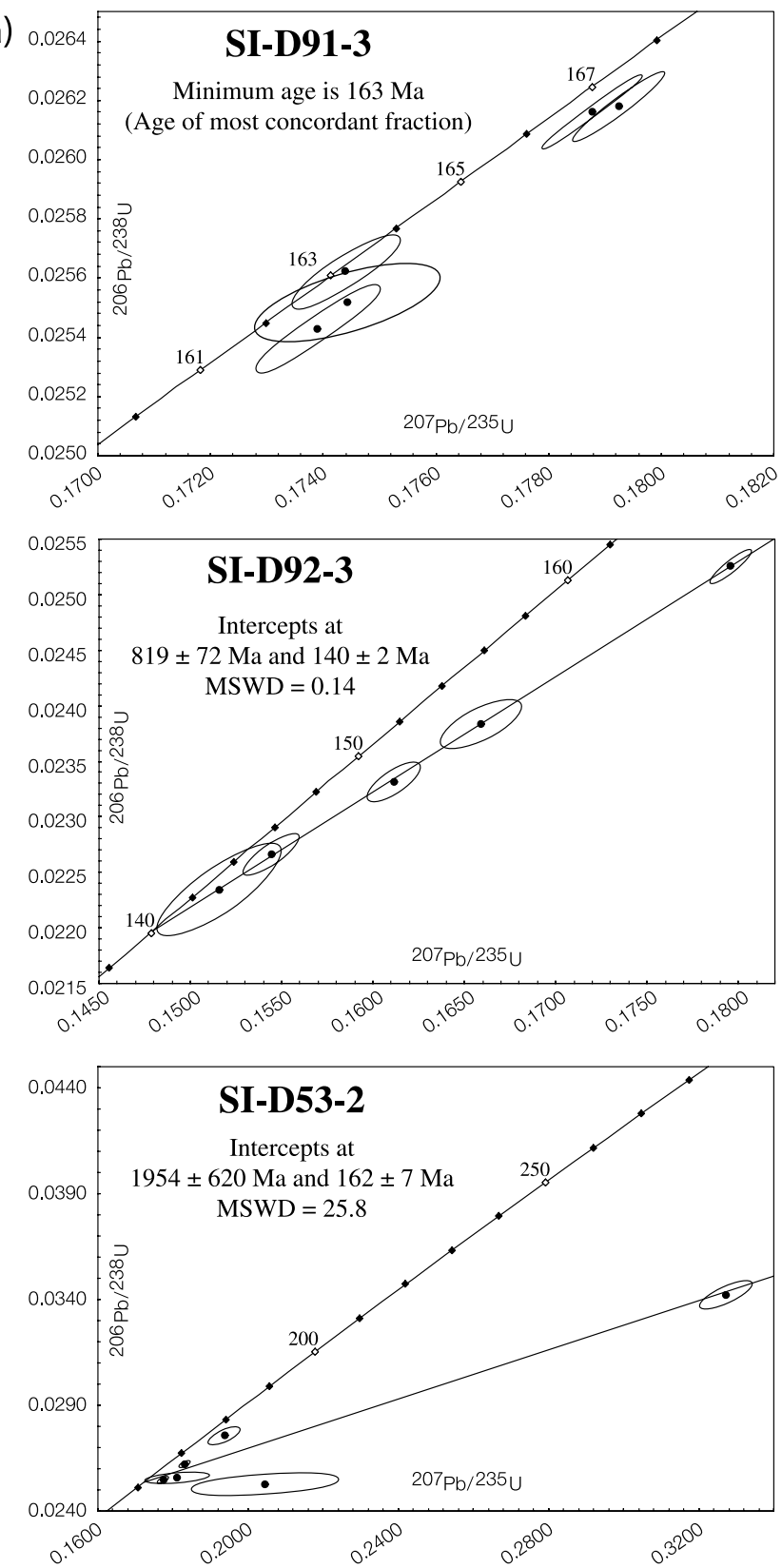
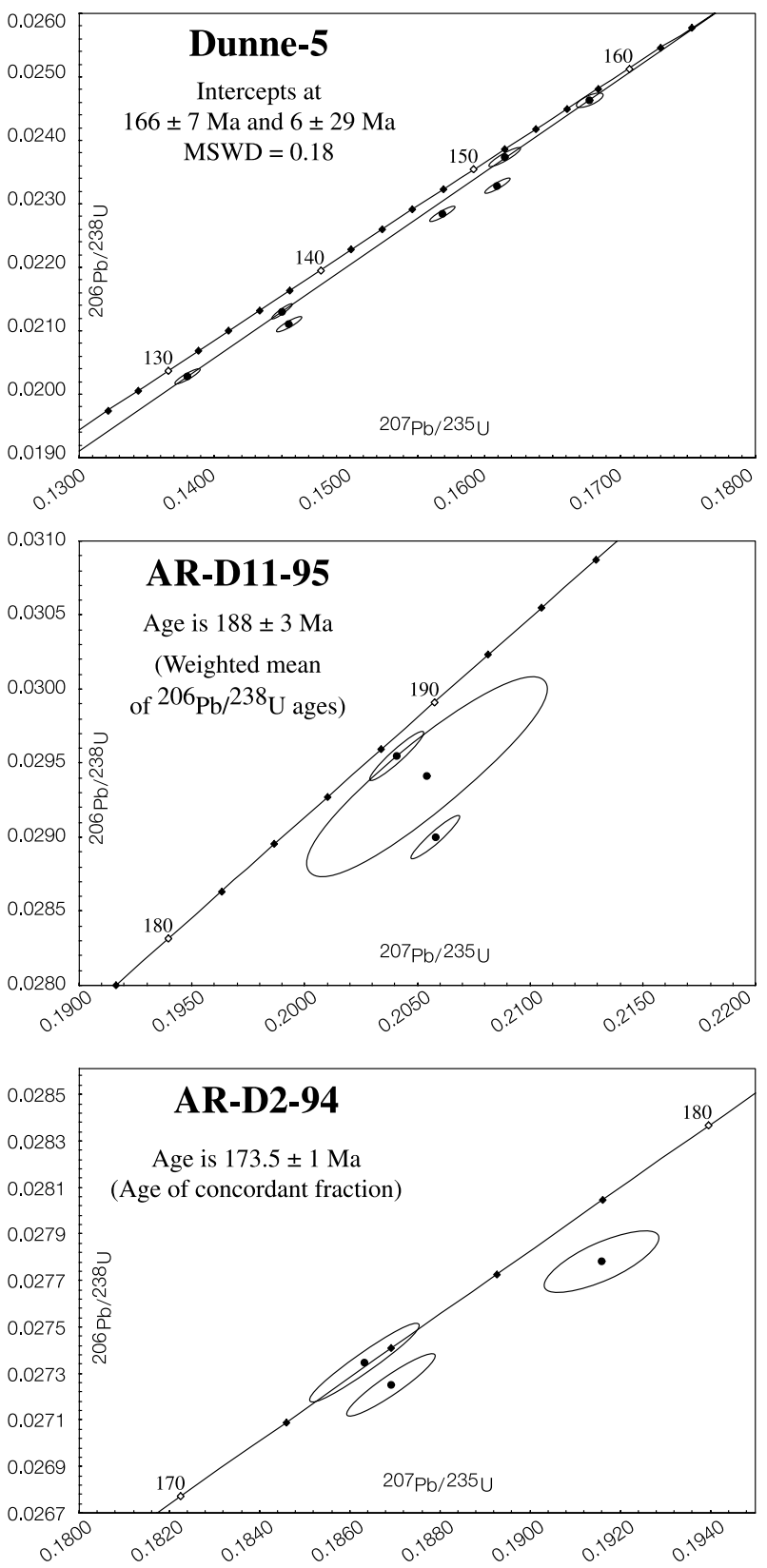

Figure 11. Diagrammatic representations of 26 new U-Pb age determinations for ESTS rocks. Isotopic data tables affiliated with these diagrams are available in the auxiliary material. (a, b, and c) Concordia diagrams of 22 analyses conducted by standard TIMS method. (d) Plots of SHRIMP-determined ${ }^{206} \mathrm{~Pb} /{ }^{238} \mathrm{U}$ ages for individual grain analyses of four samples. Error bars are at the 2-sigma level. Ages given are the weighted mean of the grain ages.

(Table 5, locations 6, 7, and 9) is consistent with this earlier interpretation, substantiating that thrusting had begun by $\sim 152$ Ma. The Flagstaff thrust deforms some $\sim 148$ Ma Independence dikes and the Layton Well thrust deforms a $>145 \mathrm{Ma}$ intrusion, suggesting either that thrusting continued for several million years, or that renewed movement occurred on the thrusts during the late interval. A post$156 \mathrm{Ma}$ thrust fault in the southern Darwin Hills (Table 3, location 7) and a post-160 Ma strand of the Argus Sterling thrust zone in the Argus Range (Table 4, location 4) also may have moved in concert with the Flagstaff and Layton Well thrusts, or they could have formed during the late interval. If the former, then a major thrusting event apparently affected the full length of the ESTS near the end of Jurassic time.

[25] Deformational events known to have occurred during the late interval are largely identified by their imposition on $\sim 148 \mathrm{Ma}$ Independence dikes and on $140 \mathrm{Ma}$ dikes in 

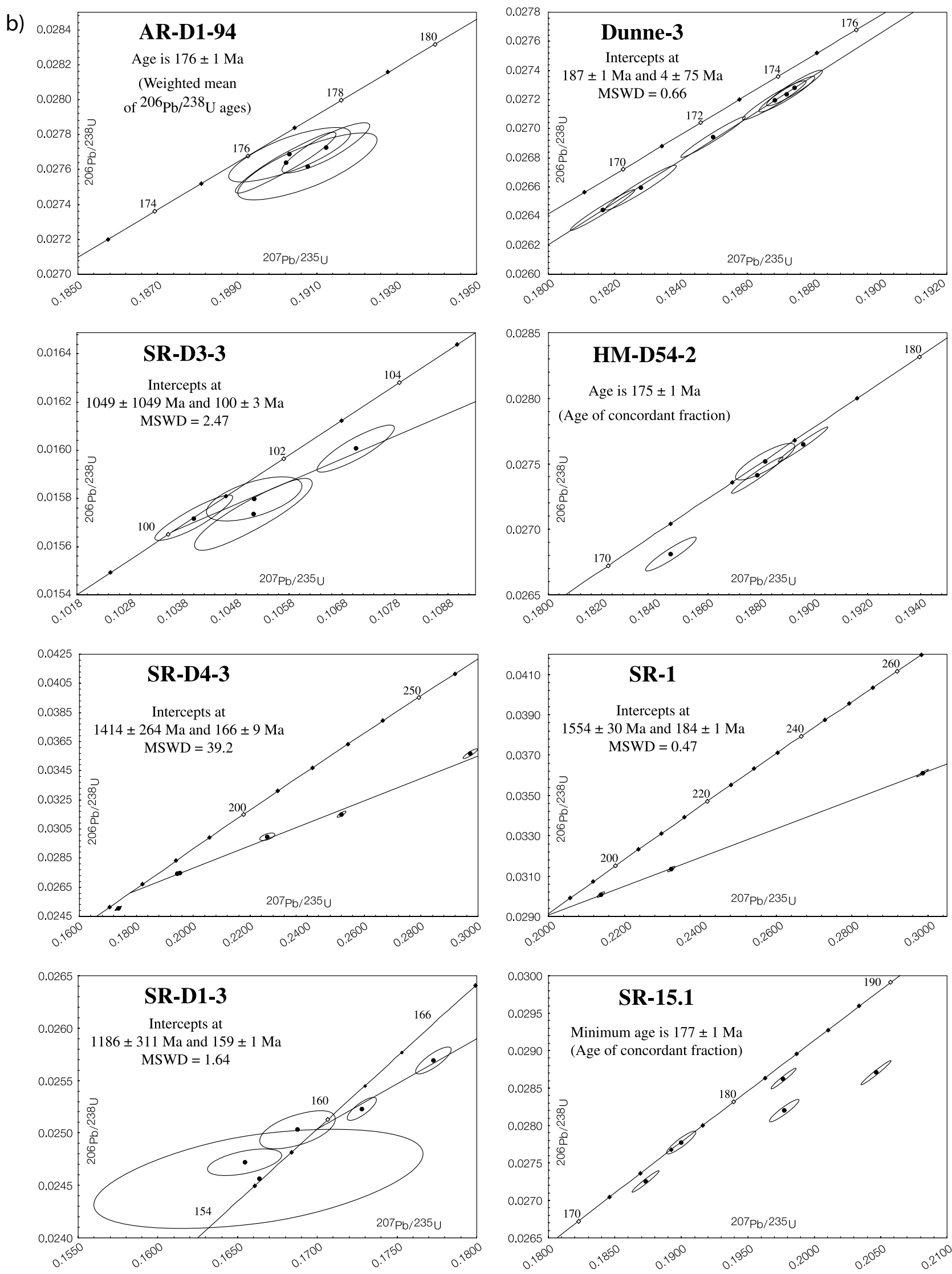

Figure 11. (continued) 
c)
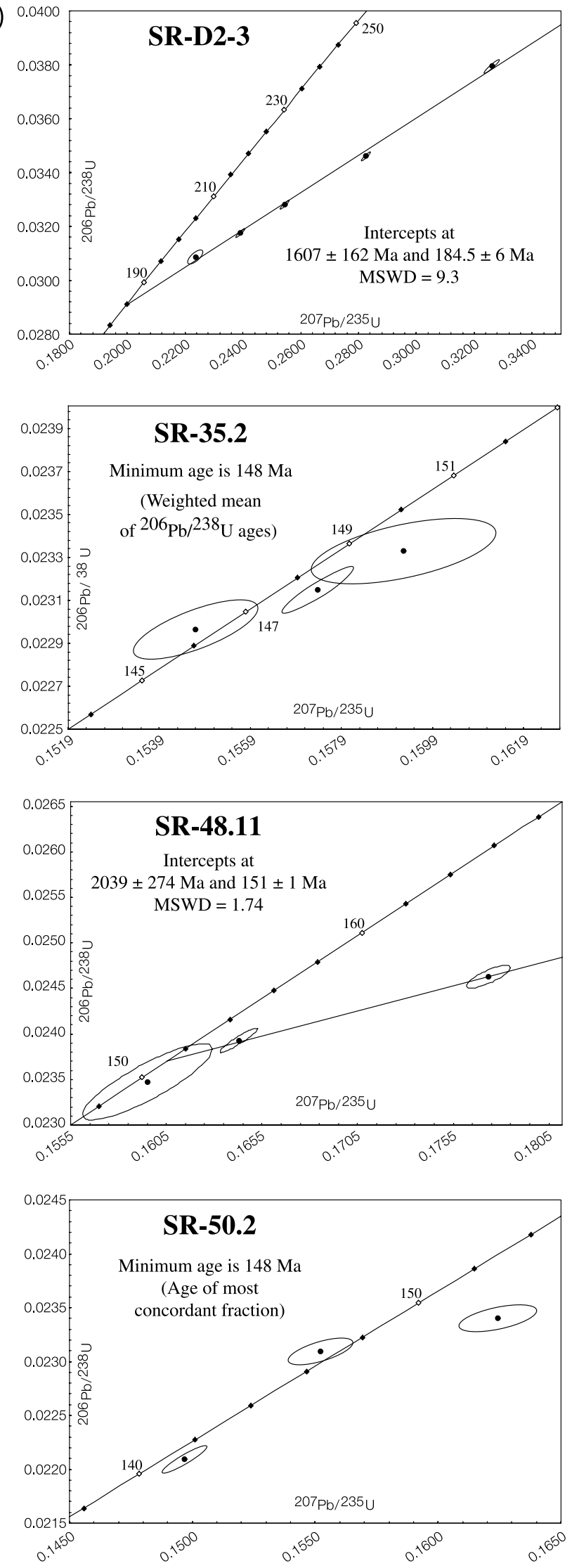
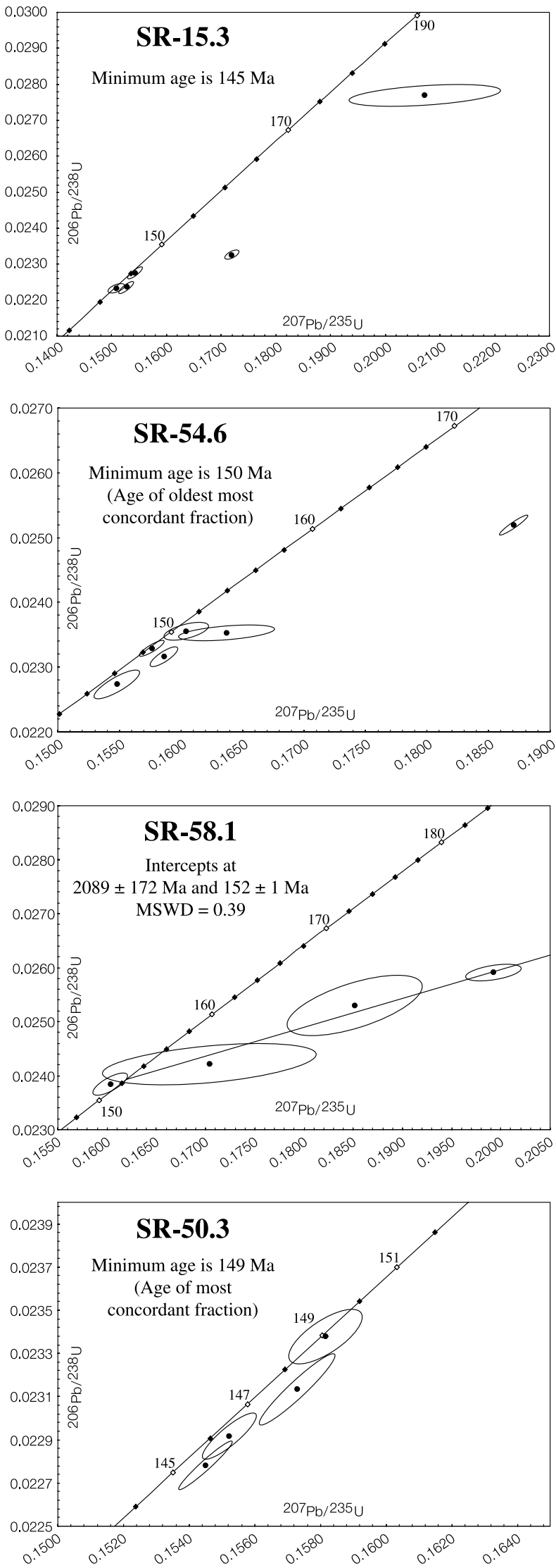

Figure 11. (continued) 

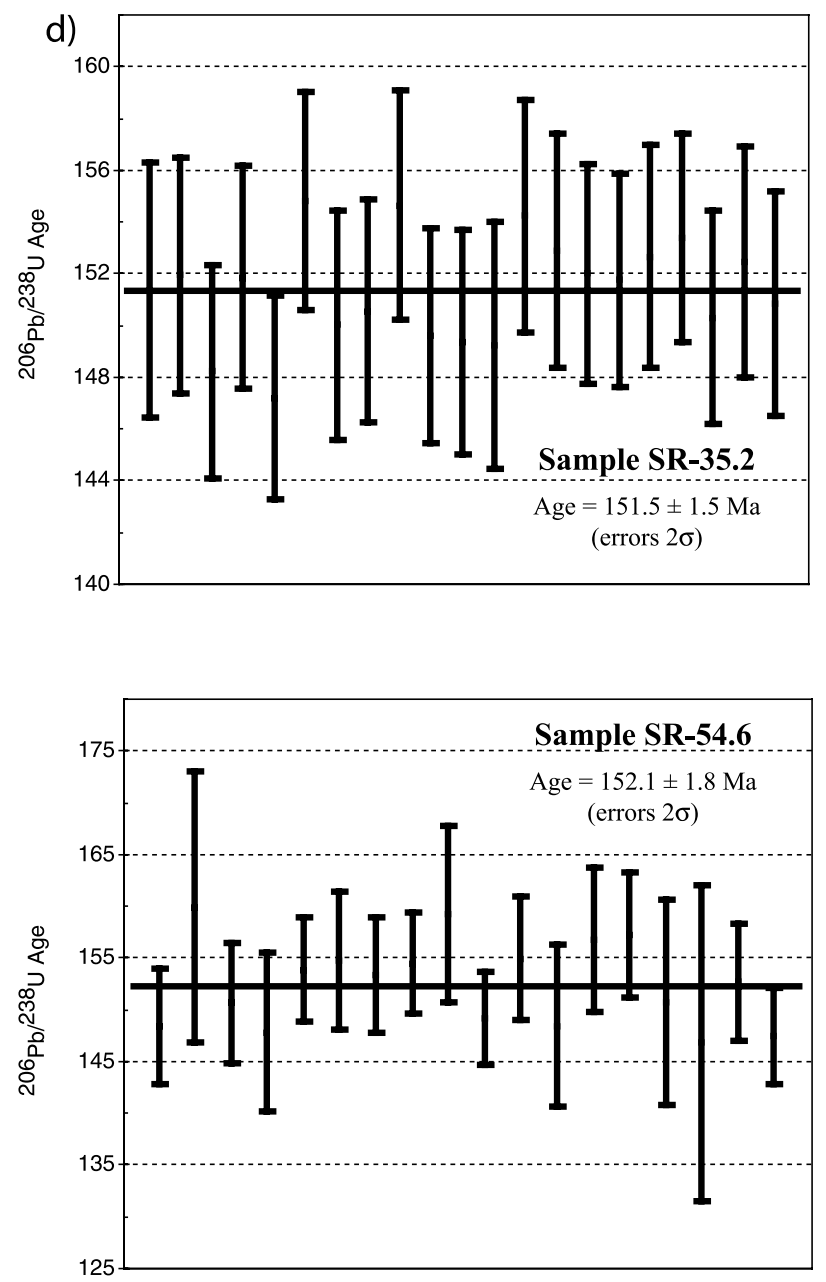

Figure 11. (continued)

the southern Inyo Mountains. Examples include the following: (1) Independence dikes are commonly truncated along the Flagstaff and Dolomite Canyon thrust faults, suggesting late interval movement of these structures; (2) Independence dikes are locally affected by cleavage that is orientated $\sim$ parallel to host rock cleavage, and that cuts across the dikes with a more northerly trend than the dikes themselves; (3) Independence dikes that cross the cores of some earlyinterval folds are boudinaged, suggesting that these folds may have tightened; (4) steeply dipping beds and Independence dikes intruded into them are locally boudinaged in crude chocolate tablet style; (5) 140 Ma dikes are affected by minor northwest trending, right-slip shear zones and are truncated by the Dolomite Canyon thrust fault (Table 2, location 3); (6) Andrew [2002] reported minor east vergent contractional structures that developed synchronously with intrusion of $75 \mathrm{Ma}$ plutons along the west flank of the Panamint Range, an area that would have represented a deeper part of the east margin of the ESTS prior to Cenozoic extension. Additional folding of typical ESTS character that locally deformed thrust faults in the Darwin Hills and central Slate Range may also have developed during the late interval. In summary, widespread contractional defor-
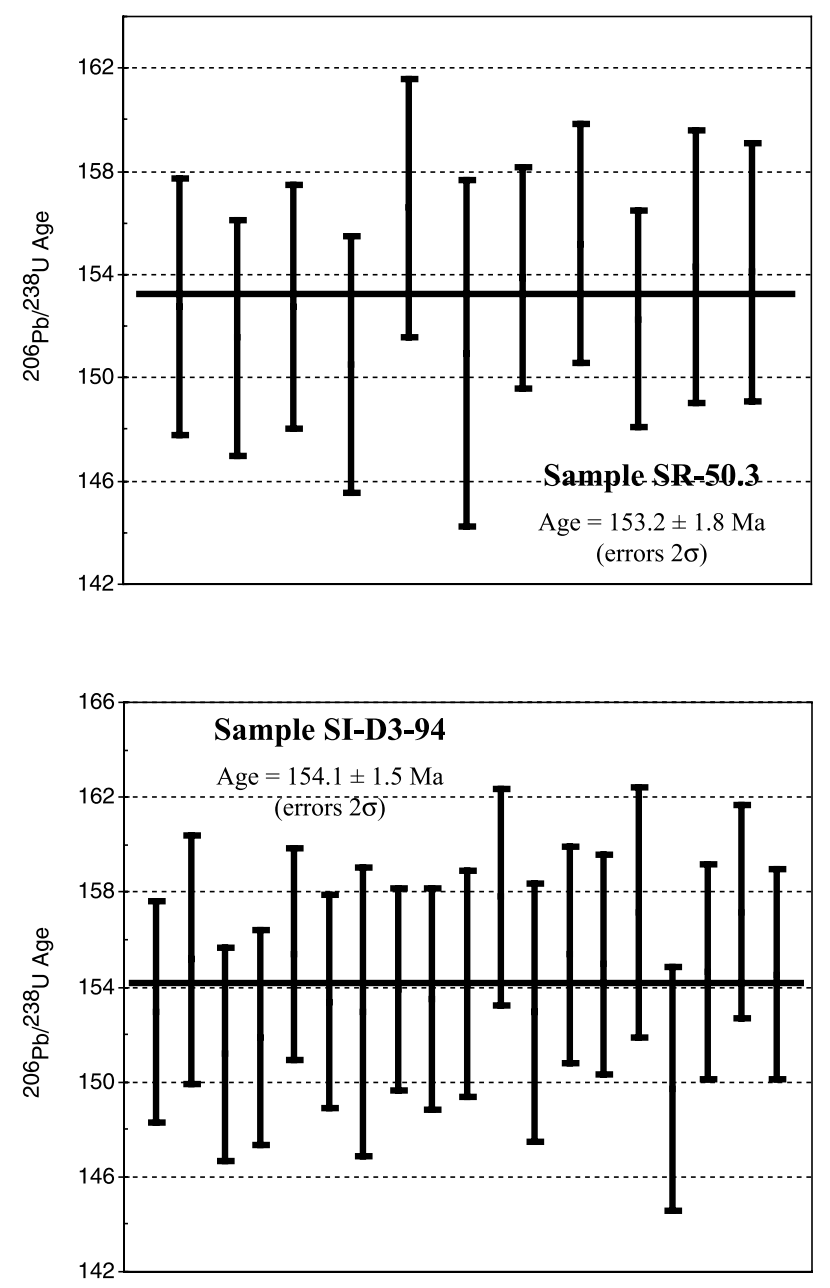

mation of apparently slight to moderate intensity occurred during the late interval.

[26] Termination of widespread contractional deformation in the ESTS is poorly constrained because of the paucity of recognized Cretaceous rocks. In the Slate Range, the undeformed, 100 Ma Stockwell pluton (Table 5, location 1) pins much of the exposed width of the ESTS, although unexposed contractional structures may underlie Searles Valley to the west. In the Alabama Hills, the undeformed 85 Ma Alabama Hills Granite postdates foliation in Jurassic volcanic strata (Table 2, location 1). In the southern Inyo Mountains, conjugate strike-slip faults developed across a substantial width of the most strongly deformed part of the ESTS, overprinting all recognized typical ESTS structures (Table 2, location16). On the basis of similarities of orientations and slip senses, Dunne [2001] hypothesized that these faults might correlate with conjugate microfaults in the Sierra Nevada that were active $\sim 79 \pm$ $3 \mathrm{Ma}$. If this correlation is correct, then most if not all arcnormal ESTS contraction in the southern Inyo Mountains was completed prior to middle Late Cretaceous time, consistent with other available time constraints. By then, regional principal stresses had apparently reoriented to favor 
Table 2. Key Structural Characteristics and Chronologic Relationships, Southern Inyo Mountains

\begin{tabular}{|c|c|}
\hline Location (Figure 2) & Feature \\
\hline 1 & $\begin{array}{l}\text { Zone of strong, NW striking, SW dipping foliation that gives way southwestward to faint foliation typical of most of } \\
\text { volcanic complex of Alabama Hills. May be related to speculative cryptic thrust fault that placed Alabama Hills volcanic } \\
\text { complex over Paleozoic strata on west flank of southern Inyo Mountains. }\end{array}$ \\
\hline 2 & $\begin{array}{l}\text { West vergent Duarte fault intruded by French Spring pluton at its south end; pluton has a U-Pb age of } 148.5 \mathrm{Ma} \text { [Dunne } \\
\text { and Walker, 1993]. }\end{array}$ \\
\hline 3 & $\begin{array}{l}\text { Complex crosscutting relations in hanging wall of Dolomite Canyon thrust support a multistep structural evolution. These } \\
\text { relations include the following: (1) NE trending dikes dated by U-Pb at } 140 \mathrm{Ma} \text { (SI-D92-3) are truncated by the Dolomite } \\
\text { Canyon fault and by contractional shear zones in the upper plate of the Dolomite fault; truncations reveal a component of } \\
\text { right drag; (2) prominent shear zone in Black Warrior pluton (163 Ma; SI-D91-3) shows a gently plunging mineral } \\
\text { lineation and drag of foliation indicating left-reverse slip sense; (3) NE trending dikes like those at location } 3 \text { a transect } \\
\text { shear zone of location 3b without offset or foliation; (4) mylonitic shear zones containing strong downdip mineral } \\
\text { lineations affect Long John pluton (175 Ma [Chen and Moore, 1982, sample 76]). }\end{array}$ \\
\hline 4 & $\begin{array}{l}\text { Youngest exposed strata of the Inyo Mountains Volcanic Complex (Dunne et al., 1998] are here truncated by the Flagstaff } \\
\text { thrust, and are intruded by the French Spring pluton (148.5 Ma [Dunne and Walker, 1993] } 2 \text { km to north. These youngest } \\
\text { volcanic strata yielded minimum U-Pb age of } 150 \mathrm{Ma} \text { via analysis of several multigrain samples [Dunne et al., 1998]. } \\
\text { Reanalysis via SHRIMP method as reported here yields } 154 \mathrm{Ma} \text { age. }\end{array}$ \\
\hline 5 & $\begin{array}{l}\text { Large anticline is intruded by Long John pluton, which has yielded a U-Pb age of } 175 \mathrm{Ma}[\text { Chen and Moore, } 1982, \\
\text { sample } 76] \text {. Numerous } \sim \text { vertical, mafic dikes that we infer to be part of the Independence swarm emplaced } \sim 148 \mathrm{Ma} \\
\text { intrude obliquely across fold without significant change in orientation, but are boudinaged near crest of fold, suggesting } \\
\text { that fold experienced slight postdike tightening. }\end{array}$ \\
\hline 6 & $\begin{array}{l}\text { Dolomite Canyon thrust affected by moderate-size fold here (and smaller, more open folds elsewhere), suggesting } \\
\text { postthrust folding episode. Latest slip on thrust truncates northeast trending } 140 \mathrm{Ma} \text { mafic dikes (but see location 9). }\end{array}$ \\
\hline 7 & $\begin{array}{l}\text { West vergent Spark Plug fault zone truncates east limb of large anticline. This fault zone may continue northward into } \\
\text { Black Warrior pluton as diffuse belt of northeast dipping shear zones. }\end{array}$ \\
\hline 8 & $\begin{array}{l}\text { Morning Star thrust coincides with "normal" stratigraphic contact between Mississippian and Pennsylvanian formations, } \\
\text { but basal strata of latter are missing in most areas, and complex imbrication zones marked by horses of various } \\
\text { Mississippian units are present along zone locally. Speculatively interpreted by Stevens et al. [1997] as a strand of the } \\
\text { Permian Death Valley thrust belt, but may also have slipped during evolution of ESTS. }\end{array}$ \\
\hline 9 & $\begin{array}{l}\text { Dolomite Canyon thrust fault and both walls are intruded by a small pluton, which has yielded a minimum } \mathrm{U}-\mathrm{Pb} \text { age of } \\
162 \mathrm{Ma} \text { (sample SI-D53-2). Pluton is affected by minor shearing along projected trace of thrust, suggesting minor thrust } \\
\text { reactivation, apparently after } 140 \mathrm{Ma} \text { (see location 6). }\end{array}$ \\
\hline 10 & $\begin{array}{l}\text { Traced northward from south end of range, Flagstaff thrust as well as regional fold-related cleavage in footwall and } \\
\text { hanging wall of thrust both rotate from moderate southwest dips that are typical of ESTS elsewhere to vertical and locally } \\
\text { to steep northeast dips. Northward from vicinity of location } 10 \text {, dips of thrust and cleavage range between } 80^{\circ} \mathrm{NE} \text { and } \\
60^{\circ} \mathrm{SW} \text {. Dolomite Canyon thrust dips also fall within this range. Most of this steepening apparently occurred prior to } \\
\text { emplacement of } \sim 148 \mathrm{Ma} \text { Independence dikes, which on average remain } \sim \text { vertical. }\end{array}$ \\
\hline 11 & Cerro Gordo anticline. \\
\hline 12 & $\begin{array}{l}\text { Complex fault and fold structures exposed in remote, steep terrain in this area speculatively inferred to be associated } \\
\text { with the Death Valley thrust belt [Stevens et al., 1997], but not yet mapped in detail. }\end{array}$ \\
\hline 13 & $\begin{array}{l}\text { Uppermost member of Early and early Middle (?) Triassic Union Wash Formation is intensely deformed by tight folds } \\
\text { and thrust faults marking a significant zone of contractional deformation. }\end{array}$ \\
\hline 14 & Prominent set of SW vergent "young" folds that deform regional cleavage cross Cerro Gordo Road. \\
\hline 15 & $\begin{array}{l}\text { Numerous strike-slip faults (shown schematically in Figure 2) form a conjugate array that cuts all other recognized } \\
\text { contractional structures. }\end{array}$ \\
\hline 16 & $\begin{array}{l}\text { Prominent upright, slightly east vergent syncline in footwall of Flagstaff thrust is truncated obliquely by more gently } \\
\text { dipping thrust. }\end{array}$ \\
\hline 17 & Local west vergent thrust fault of modest slip [Swanson, 1996]. \\
\hline 18 & $\begin{array}{l}\text { Northeast trending, southeast vergent fold of Death Valley thrust belt is strongly overprinted by northwest trending folds } \\
\text { and cleavage of ESTS [cf. Werner, 1979]. }\end{array}$ \\
\hline 19 & $\begin{array}{l}\text { NE trending, SE vergent folds and thrust of Death Valley thrust belt overlapped westward by Early Triassic Union Wash } \\
\text { Formation [Swanson, 1996]. }\end{array}$ \\
\hline 20 & $\begin{array}{l}\text { Folds and thrust faults of Permian age [Stevens and Stone, 1988] are overprinted by NW trending ESTS folds and regional } \\
\text { cleavage. }\end{array}$ \\
\hline
\end{tabular}

development of conjugate strike-slip faults that accommodated $\sim \mathrm{N} 45^{\circ} \mathrm{E}$ oriented contraction.

\section{ESTS in Regional Context}

\subsection{Correlative Structures to North and South}

[27] Some contractional structures exposed on-strike with the ESTS to the north and south may be broadly correlative with the ESTS based on similarities of orientation, age, deformational character, and back arc (or arc-fringe) set- tings. Whether they represent preserved remnants of formerly continuous extensions of the ESTS or locally developed subregions that experienced similar contraction is unknown. To the north, north to northwest trending, predominantly upright to east vergent folds with axial cleavage are widespread in the northern Inyo Mountains, southern White Mountains, and adjacent Benton Range [Morgan and Law, 1998; Stevens et al., 1997; Welch and Dunne, 1999]. Some of these folds are of Middle Jurassic age [Coleman et al., 2003], others are intruded by undeformed Middle Jurassic plutons [Morgan and Law, 1998], 
Table 3. Key Structural Characteristics and Chronologic Relationships, Darwin Plateau

\begin{tabular}{|c|c|}
\hline Location (Figure 3) & Feature \\
\hline 1 & $\begin{array}{l}\text { Talc City thrust, part of Permian Death Valley thrust belt, is folded by large ESTS folds. Footwall strata are } \\
\text { isoclinally folded and mostly inverted, and inferred to compose allochthonous thrust plate } 3 \text { of Stone et al. [1989]. }\end{array}$ \\
\hline 2 & $\begin{array}{l}\text { Diffuse, SW dipping shear zones locally containing strong downdip mineral lineation and weakly developed } \\
\text { reverse-sense fabrics are present in Jurassic (?) pluton. Zones locally affect mafic, NW trending dikes that may } \\
\text { be part of Independence swarm }(\sim 148 \mathrm{Ma}) \text {. }\end{array}$ \\
\hline 3 & $\begin{array}{l}\text { Small diorite plug, assumed to be outlier of main Darwin pluton exposed just to east, intrudes Ophir Peak } \\
\text { thrust fault. Main pluton has yielded U- } \mathrm{Pb} \text { date of } 175 \text { Ma [Chen and Moore, 1982, sample 77]. However, north } \\
\text { of this plug, same thrust clearly truncates several other dioritic intrusions inferred to be outliers of Darwin pluton, } \\
\text { thus suggesting a possible composite slip history. Ophir Peak thrust is folded by typical ESTS folds. }\end{array}$ \\
\hline 4 & $\begin{array}{l}\text { Prominent folds of typical ESTS style that deform Paleozoic strata in Darwin Hills, here involve Early } \\
\text { Triassic strata of Union Wash Formation. }\end{array}$ \\
\hline 5 & $\begin{array}{l}\text { Darwin tear fault and other brittle NW to west trending left-slip faults farther south truncate all other } \\
\text { contractional structures that they encounter and may be genetically related to conjugate strike-slip } \\
\text { faults in Inyo Mountains. }\end{array}$ \\
\hline 6 & $\begin{array}{l}\text { Prominent contact metamorphic zone developed along east side of Darwin pluton }(175 \mathrm{Ma}) \text { here clearly } \\
\text { overprints previously formed folds that are part of the fold group that involves Early Triassic strata at location } 4 \text {. }\end{array}$ \\
\hline 7 & $\begin{array}{l}\text { Eastern margin of this pluton (156 Ma by U-Pb [Chen and Moore, } 1982 \text {, sample } 78] \text { ) at its contact with } \\
\text { Paleozoic strata contains a SW dipping mylonitic foliation featuring a WSW trending mineral lineation. We infer } \\
\text { pluton was thrust over its Paleozoic wall rocks, a relationship that is common southward from this location. }\end{array}$ \\
\hline 8 & $\begin{array}{l}\text { Eastward overturned syncline is obliquely transected by numerous NW trending mafic dikes that are } \\
\text { inferred to be part of the Independence dike swarm }(\sim 148 \mathrm{Ma}) \text {. }\end{array}$ \\
\hline 9 & $\begin{array}{l}\text { Argus Range anticline is strongly deflected and locally overturned to the southwest by forcible emplacement } \\
\text { of the French Madam pluton, for which we have determined a U-Pb date of } 176 \mathrm{Ma} \text { (sample AR-D1-94). }\end{array}$ \\
\hline
\end{tabular}

Table 4. Key Structural Characteristics and Chronologic Relationships, Central Argus Range

\begin{tabular}{|c|c|}
\hline Location (Figure 4) & Feature \\
\hline 1 & $\begin{array}{l}\text { Undeformed Argus Sterling pluton intrudes mylonitic carbonate rock of Argus Sterling fault and also intrudes Bendire } \\
\text { pluton. Argus Sterling pluton has yielded approximate U-Pb date of } 166 \pm 6 \mathrm{Ma} \text {. (Sample Dunne-5). }\end{array}$ \\
\hline 2 & $\begin{array}{l}\text { Much of lower western face of Maturango Peak block contains a NW striking, SW dipping, weakly developed foliation } \\
\text { that may have formed during evolution of ESTS, then been exploited by Cenozoic range-front normal fault. }\end{array}$ \\
\hline $3 a, 3 b$ & $\begin{array}{l}\text { As noted by Moore [1976], Bendire pluton intruded a 6-km length the Argus Sterling fault zone. Chen and Moore } \\
\text { [1982, sample 79] reported U-Pb date of } 185 \mathrm{Ma} \text { for sample from location } 3 \mathrm{~b} \text {, and we report here a new U-Pb date of } \\
188 \mathrm{Ma} \text { (sample AR-D11-93) for a sample from location 3a. Undeformed dikes of Bendire pluton transect Argus } \\
\text { Sterling mylonite zone just east of location 3a. }\end{array}$ \\
\hline 4 & $\begin{array}{l}\text { Mylonitic granite in the Maturango Peak pluton forms a separate, previously unidentified, apparently continuous fault } \\
\text { zone that converges with and apparently merges into the main part of the Argus Sterling fault zone at the transverse } \\
\text { Millspaugh fault. Given the } \sim 160 \mathrm{Ma} \text { age of the Maturango Peak pluton (see location } 11 \text {, below), this fault zone } \\
\text { (referred to informally as the Maturango Peak zone) represents a younger part of the Argus Sterling fault zone than } \\
\text { does the main part of the zone that predates the } \sim 186 \mathrm{Ma} \text { Bendire pluton. The northeasternmost fringe of this zone } \\
\text { locally affects southwesternmost exposures of the Bendire pluton. }\end{array}$ \\
\hline 5 & Several moderate-size folds that are locally southwest vergent seem to predate enclosing Hunter Mountain pluton. \\
\hline 6 & $\begin{array}{l}\text { Sample of Hunter Mountain pluton collected here has yielded a new U-Pb date of } 173 \pm 1 \mathrm{Ma} \text { (sample AR-D2-94), } \\
\text { consistent with K/Ar (hornblende) date of } 169 \pm 6 \mathrm{Ma} \text { determined for a sample of the same pluton by Moore [1976]. } \\
\text { This pluton, largely undeformed where we have examined it, postdates folding of Paleozoic host rock. }\end{array}$ \\
\hline 7 & Bendire anticline folds both Paleozoic and Early to early Middle (?) Triassic strata. \\
\hline 8 & $\begin{array}{l}\text { The Cenozoic (?) left-oblique Millspaugh fault lifted north wall } \sim 1 \mathrm{~km}[\text { Moore, 1976]. Abrupt change in style of the } \\
\text { Argus Sterling fault zone as it crosses this fault apparently reflects change in fault zone style with increasing depth, } \\
\text { with shallower parts of zone exposed south of Millspaugh fault featuring imbricate lenses of diverse rock units. }\end{array}$ \\
\hline 9 & $\begin{array}{l}\text { This small pluton is one of several elongate, medium- to fine-grained leucocratic granite intrusions that intruded along } \\
\text { parts of Argus Sterling fault zone. We concur with the inference of Moore [1976] that these plutons exploited the } \\
\text { previously formed fault zone and are broadly syntectonic. Some of these intrusions are undeformed and postdate } \\
\text { activity along the parts of the Argus Sterling fault zone that they intrude. Body at this location intrudes across and } \\
\text { apparently postdates part of the zone but is strongly foliated in its western exposures where it is proximal to the } \\
\text { mylonitic zone noted at location } 4 \text {. This pluton has yielded a U-Pb date of } \sim 187 \pm 8 \mathrm{Ma} \text { (sample Dunne-3). }\end{array}$ \\
\hline 10 & $\begin{array}{l}\text { A large syncline, subsidiary to the Bendire anticline, is truncated by the Hunter Mountain pluton ( } 173 \mathrm{Ma} \text {; } \\
\text { see location } 6 \text {, above). Thus this fold set postdates the Early Triassic Union Wash Formation and predates } 173 \mathrm{Ma} \text {. }\end{array}$ \\
\hline 11 & $\begin{array}{l}\text { Sample of Maturango Peak pluton collected at this location yielded a U-Pb date of } 160 \mathrm{Ma} \text { [Chen and Moore, } 1982 \text {, } \\
\text { sample 80], consistent with a K/Ar (hornblende) date of } 165 \pm 5 \mathrm{Ma} \text { reported for this pluton by Moore [1976]. }\end{array}$ \\
\hline
\end{tabular}


Table 5. Key Structural Characteristics and Chronologic Relationships, Slate Range

\begin{tabular}{|c|c|}
\hline Location (Figure 5) & Feature \\
\hline 1 & $\begin{array}{l}\text { Dioritic Stockwell pluton (100 Ma; sample SR-D3-3) is undeformed, thus places younger age limit on } \\
\text { deformation across nearly the entire width of the footwall of the Ophir thrust fault. }\end{array}$ \\
\hline 2 & $\begin{array}{l}\text { Ophir thrust fault truncates Permian (?) strata in hanging wall and previously folded Early Triassic strata in } \\
\text { footwall, and was itself folded during or following emplacement. }\end{array}$ \\
\hline 3 & $\begin{array}{l}\text { Alaskitic Copper Queen pluton }(159 \pm 1 \mathrm{Ma} \text {; sample SR-D1-3) is undeformed, intrudes folded Early Triassic } \\
\text { strata of Ophir thrust footwall. }\end{array}$ \\
\hline 4 & $\begin{array}{l}\text { Alaskitic Gold Bottom pluton (184.5 } \pm 6 \mathrm{Ma} \text {; sample SR-D2-3) affected by widespread foliation development, } \\
\text { then by semiductile chevron-style folding of the foliation. Inferred to intrude thrust in Mesozoic strata of } \\
\text { hanging wall of Ophir thrust. }\end{array}$ \\
\hline 5 & $\begin{array}{l}\text { Metavolcanic rocks contain a strong foliation and SW trending stretching lineation near the Layton Well thrust } \\
\text { that is roughly parallel to the thrust. Kinematic indicators record top-to-the-northeast sense of shear. } \\
\text { Conventional U-Pb zircon data indicate a minimum age of } 149 \mathrm{Ma} \text { (samples SR } 50.2 \text { and SR } 50.3 \text { ), whereas } \\
\text { SHRIMP data (on sample SR 50.3) indicate an age of } 153 \mathrm{Ma} \text { for these rocks. These data indicate that the } \\
\text { Layton Well thrust is post } \sim 153 \mathrm{Ma} \text {. }\end{array}$ \\
\hline 6 & $\begin{array}{l}\text { The Layton Well thrust is a prominent zone of strongly mylonitized rocks. Intense deformation extends up to } \\
200 \mathrm{~m} \text { above the thrust. Rocks along the thrust are laminated cataclasite, mylonite, and chlorite schist that } \\
\text { overprint earlier, quartz-ductile crystal-plastic mylonites. Fabrics in the hanging wall are roughly parallel to the } \\
\text { thrust, but are locally slightly oblique }\left(10^{\circ} \text { or less). Kinematic indicators record top-to-the-northeast sense of }\right. \\
\text { shear. Hanging wall rocks consist of a mixed suite of granitic to dioritic/gabbroic plutons. Ages of hanging wall } \\
\text { rocks range from } 184 \pm 1 \mathrm{Ma} \text { to } 151 \pm 1 \mathrm{Ma} \text { (samples SR-1, SR 15.1, SR 48.11, and SR 58.1; see text and Table 1). } \\
\text { These relations indicate that the Layton Well thrust experienced post } \sim 151 \mathrm{Ma} \text { movement. }\end{array}$ \\
\hline 7 & $\begin{array}{l}\text { The footwall pluton in this location intrudes the metavolcanic rocks. The pluton is cataclastic within } 30 \mathrm{~m} \text { of } \\
\text { the thrust, but otherwise appear to cut thrust-parallel fabric in the metavolcanic rocks of footwall. Ubiquitous } \\
\text { miarolitic cavities indicate pluton was emplaced at shallow depth. Horses of this rock are present to the east } \\
\text { along the thrust fault. This pluton is interpreted to be synkinematic with movement on the Layton Well thrust. } \\
\text { Conventional U-Pb zircon data indicate a minimum age of } \sim 148 \mathrm{Ma} \text { (sample SR } 35.2 \text { ), whereas reanalysis by } \\
\text { SHRIMP method indicates an age of } 152 \mathrm{Ma} \text { for pluton. These data indicate that latest movement on the } \\
\text { Layton well thrust was post } \sim 152 \mathrm{Ma} \text {. }\end{array}$ \\
\hline 8 & $\begin{array}{l}\text { Footwall granitic rocks contain pendants of mylonitic rocks identical to the deformed hanging wall plutonic } \\
\text { suite. This indicates that the footwall granite is probably synkinematic to the Layton Well thrust. }\end{array}$ \\
\hline 9 & $\begin{array}{l}\text { The hanging wall of the Layton Well thrust contains an extensive and mappable biotite granite body that is } \\
\text { truncated downward by the thrust. The granite is mylonitic near the thrust. This rock is dated at } 151 \pm 1 \mathrm{Ma} \\
\text { (sample SR 48.11). This relationship indicates that latest movement on the Layton Well thrust was post-151 Ma. }\end{array}$ \\
\hline 10 & $\begin{array}{l}\text { At this location the mixed plutonic suite contains the oldest dated phase. A sample of mylonitic diorite from } \\
\text { here is dated at } 184 \pm 1 \mathrm{Ma} \text { (sample SR-1). }\end{array}$ \\
\hline
\end{tabular}

and some may be of Middle Triassic age [Stevens et al., 1997]. North trending folds in the Benton Range predate $\sim 148$ Ma dikes [Renne et al., 1999]. Thus many of these folds are temporally and geometrically correlative with middle interval and/or early interval structures of the ESTS.

[28] The 48-km-long, SW dipping, reverse-sense White Mountain fault zone locally emplaced early Paleozoic strata eastward over a footwall of Mesozoic plutonic and metavolcanic rock, the latter having yielded $\mathrm{U}-\mathrm{Pb}$ ages as young as $\sim 147 \mathrm{Ma}$ [Hanson et al., 1987]. These characteristics are remarkably similar to those of the Flagstaff thrust in the southern Inyo Mountains. Also, as in the latter region, local west vergent structures overprint the White Mountain fault zone; these younger structures predate a $100 \mathrm{Ma}$ pluton [Hanson et al., 1987].

[29] Two generations of contractional structures in the Saddlebag roof pendant, presently $\sim 50 \mathrm{~km} \mathrm{NW}$ of the Benton Range/White Mountains area, but possibly located due west in Jurassic time [Stevens et al., 1997, Figure 12], may also be broadly correlative with the ESTS. An east vergent thrust formed at $\sim 220 \mathrm{Ma}$ is overprinted by NE vergent folds, thrust faults, and cleavage that deform Middle (?) Jurassic volcanic rock; these latter structures are intruded by an undeformed 168 Ma pluton [Schweickert and Lahren, 1993, 1999].

[30] Confident identification of structures potentially dcorrelative with the ESTS located north of the Saddlebag
Lake/northern White Mountains region is difficult because of the uncertain effects of a $>110 \mathrm{~km}$ eastward deflection (Figure 1) of all prior to late Mesozoic rock units and structures [Stewart, 1985, and references therein], and because of the uncertain location and slip amount of the Mojave-Snow Lake fault [Schweickert and Lahren, 1990]. We concur with and expand upon the informal suggestions by Schweickert and Lahren [1990] and Taylor et al. [1993] that the most likely northern correlative of the ESTS is the Luning-Fencemaker fold-thrust belt of western Nevada (Figure 1). Despite significant differences in the kinematic and geometric characteristics of these two belts, such a correlation of these two belts is warranted by similar locations along the eastern margin of the same magmatic arc (Figure 1) and by at least partly coeval multiphase Early (?) and Middle Jurassic to Cretaceous deformational histories [Wyld et al., 2001]. At its southern end, the LuningFencemaker belt (LFB), represented by the Luning and Pamlico thrusts [Oldow, 1984], is last observed striking west toward the northern White Mountains, thus seeming to form a connecting bridge to the ESTS.

[31] The Jurassic history of the LFB differs from that of the ESTS in that (1) it experienced a much larger amount of contraction; (2) its shortening axis was oriented NW-SE; and (3) its deformational style was characterized by complexly imbricated, gently dipping, large-slip thrust 


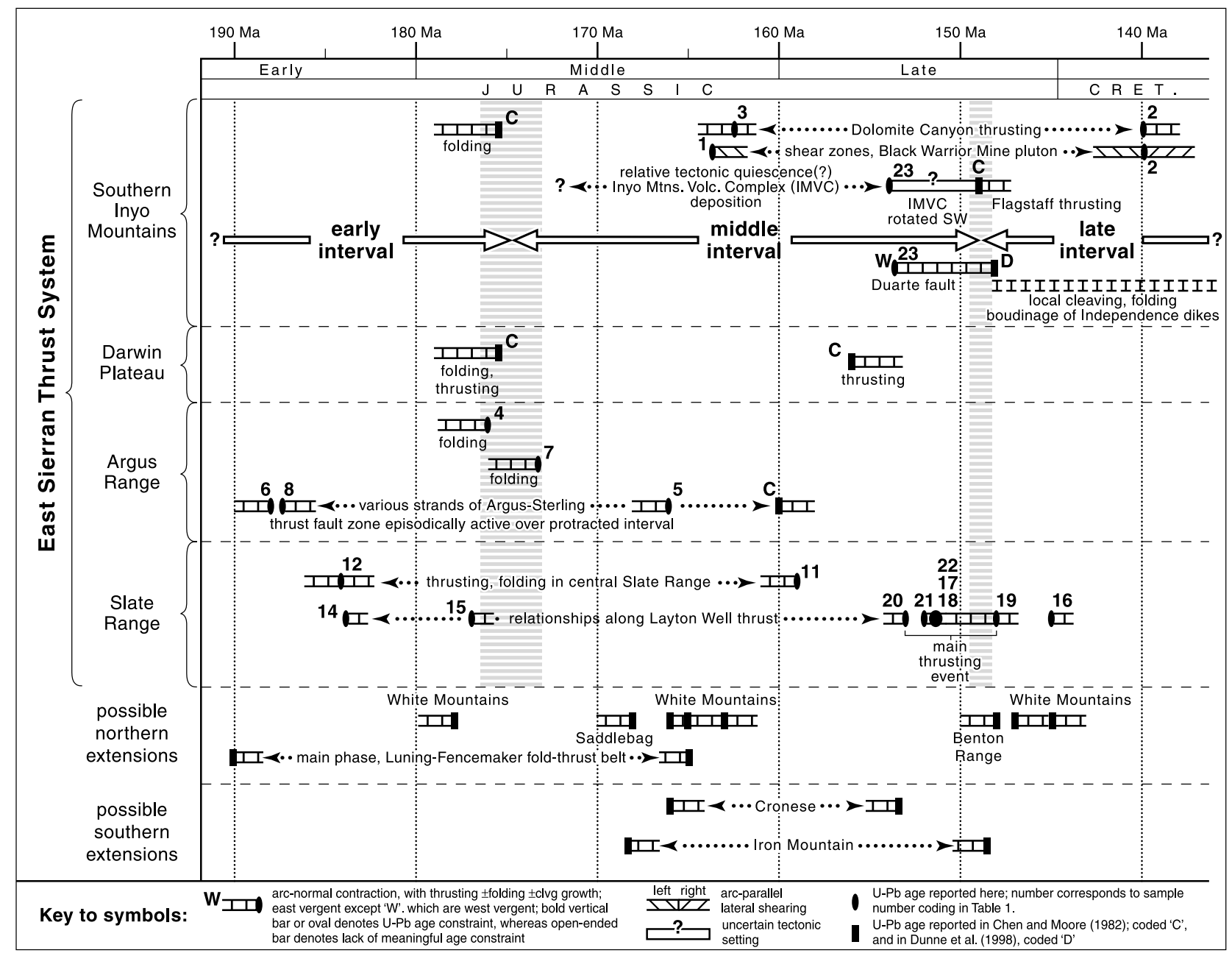

Figure 12. Schematic temporal evolution chart for the ESTS and possible extensions to the north and south. Literature citations for ages of features located in northern and southern extensions are provided in the text. Gray scale vertical columns separating the three deformational intervals represent episodes of Middle and Late Jurassic intrusion used to define the intervals. In cases where given samples have been dated by both TIMS and SHRIMP methods, the SHRIMP age is plotted here.

nappes. Possible factors that may have contributed to these differences include (1) speculatively, a more northerly or northeasterly orientation of the plate margin at the latitude of northern Nevada, thus creating a local restraining bend within the predominantly left-oblique convergence regime that is inferred to have existed during much of the Jurassic [Saleeby and Busby-Spera, 1992]; and (2) the distinctive orientation, geometry, and mechanical character of the sedimentary basin fill and basin margin system out of which the LFB evolved [cf. Elison and Speed, 1989]; these latter characteristics were very different from the geologic setting in which the ESTS evolved.

[32] Although we are reasonably confident of the likely correlation of the LFB and ESTS, the geometric and kinematic nature of the transition between these two belts remains unclear. Tracked southwestward along its delimiting basin margin, the LFB eventually encounters the east margin of the $\sim$ north trending arc. It may be that at this point, reduction of lithospheric strength induced by arc magmatism was sufficiently pronounced as to assume control of the locus of contraction, such that the LFB stopped tracking its basin margin and instead swung southward to track the east margin of the arc. If this is so, then we might further speculate, broadly in concert with the Pine Nut fault concept of Oldow [1984], that southward from this transition, most or all of the leftlateral arc-parallel component of LFB contraction may have been transposed into one or more arc-parallel leftslip faults within or adjacent to the Sierran arc, whereas only the modest arc-normal component of contraction continued southward as the ESTS and/or as other arcparallel contraction zones within or behind the arc. This hypothesis is partly analogous to that utilized by Burchfiel and Davis [1975] and Walker et al. [1995] to explain the change in trend and style of the Sevier foldthrust belt as it tracked southwestward along a depositional hinge line into the eastern edge of the arc in the eastern Mojave Desert. 


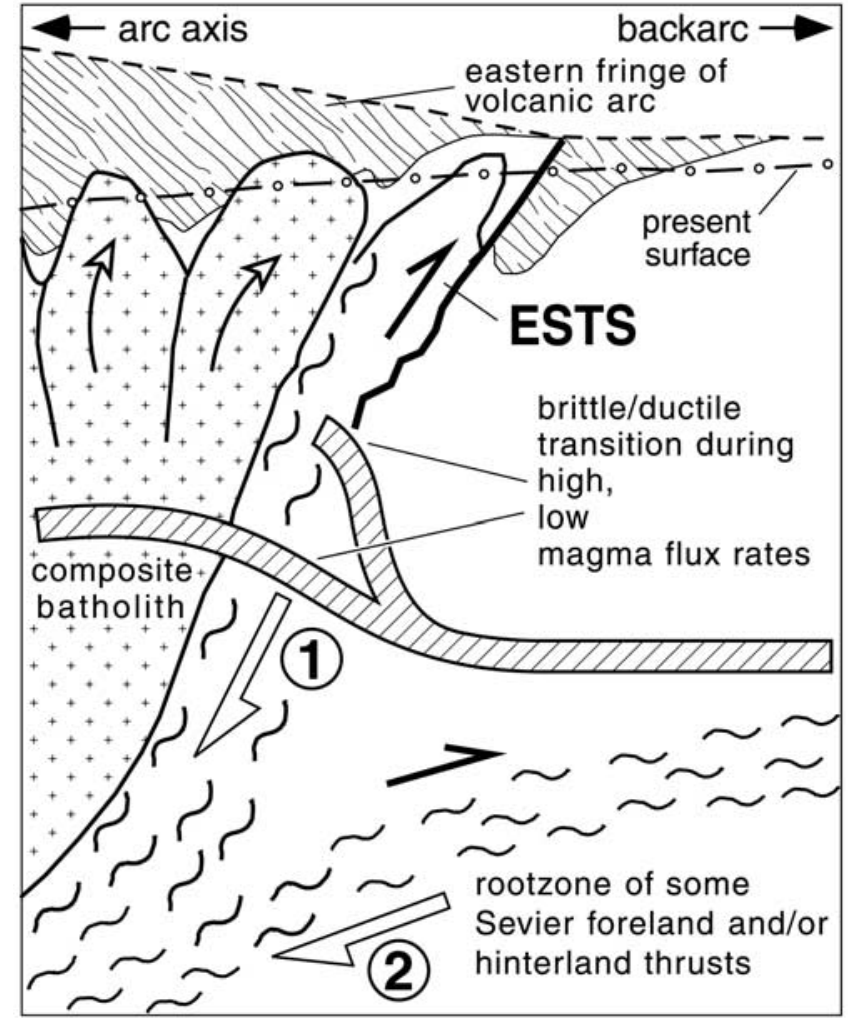

Figure 13. Schematic cross section depicting possible genetic linkages between emplacement of the Sierran batholith and evolution of the type region of the ESTS. Unpatterned material represents pre-Middle Triassic host rock of arc. Large, hollow arrows numbered 1 and 2 represent wall rock return flow and back arc underthrusting mechanisms, respectively, as discussed in the text.

[33] South of the Garlock fault, contractional structures that may be correlative with the ESTS crop out in three locations in the Mojave Desert (Figure 1). Rock units and contractional structures strikingly similar to those associated with the Layton Well thrust fault crop out in the Granite Mountains [Davis and Burchfiel, 1973]. Farther southwest, contractional faults and related structures of Middle Jurassic age inferred to be correlative with the ESTS become more steeply dipping and strike northeast, as in the Cronese Hills [Walker et al., 1990] and, more speculatively, at Iron Mountain southwest of Barstow [Boettcher and Walker, 1993]. If these correlations are valid, then the locational controls for the ESTS must have changed, because these exposures of the ESTS trend SW obliquely across the arc. Walker et al. [2002] have speculated that in this region, the ESTS may have tracked the cryptic, late Paleozoic leftlateral fault zone marking the truncated boundary of southwestern North America.

\subsection{ESTS-Magmatic Arc Genetic Links}

[34] Spatial adjacency, temporal overlap, and the fact that, on average, deformation in the ESTS is strongest next to the batholith, clearly invite the speculation that contrac- tion in the ESTS and growth of the Sierran arc were genetically related. Both features were linked to ongoing oblique subduction along the convergent plate boundary to the west, which triggered arc magmatism and established back arc stress fields that had a dominant arc-normal component, as is the case in most Cordilleran-style back arc regions today [Zoback, 1992]. Episodically, normally subordinate arc-parallel shear stress components, left-lateral in Late Jurassic time [cf. Carl et al., 1998] and right-lateral in Late Cretaceous time [cf. Tobisch et al., 2000], apparently influenced deformation in the east part of the arc and the immediate back arc.

[35] Two contrasting models, wall rock return flow and underthrusting of the arc flank, have been proposed that link Cordilleran arc growth and back arc contractional belts (Figure 13). Espousing the first model, Saleeby and Busby-Spera [1992, Plate 5, insert cross section of panel D] hypothesized that downward return flow of ductile wall rocks along the flanks of rising magma bodies, perhaps coupled with ductile flattening of these rocks, propagated upward into the upper crust as the ESTS. Two lines of reasoning suggest to us that the downflow process played a subordinate role in evolution of the ESTS. First, plutonward tilting of batholith wall rocks has commonly been ascribed to return flow combined with ductile deformation and a simple model for the process has been proposed [Tobisch et $a l ., 2000]$. However, neither the inherent properties of the model nor field observations in areas inferred to have been affected by downflow [Paterson and Miller, 1998] seem to be consistent with development of gently to moderately plunging folds and of contractional faults with vergence away from the intrusion, essential geometric characteristics of the ESTS. Moreover, we find it hard to conceive of a downflow model that would produce thrust faulting with relatively uniform kinematics over a lateral reach of almost $150 \mathrm{~km}$, as was the case for the ESTS during the Late Jurassic. Second, temporal correlation between major intrusive episodes in the arc and deformational episodes in the ESTS is poor. Although the greatest pulse of intrusion occurred between $\sim 100 \mathrm{Ma}$ and $\sim 85 \mathrm{Ma}$ [Ducea, 2001], available evidence indicates relatively weak deformation in the ESTS during this time span. Conversely, during the Late Jurassic, ESTS-wide main contraction episode, comparatively modest volumes of magma were being intruded in the Sierran arc [Ducea, 2001].

[36] Wall rock downflow may, however, have had a subordinate influence on evolution of the ESTS in two ways. (1) Downflow that facilitated emplacement of Late Jurassic plutons in the Sierran arc may have contributed to southwestward rotation of the ESTS that immediately preceded widespread thrust faulting. (2) In the southern Inyo Mountains, pronounced subvertical stretching that effected wide areas of the upper plate of the Flagstaff thrust fault during the late interval, as evidenced by boudinaged Independence dikes, may reflect ductile flattening and wall rock downflow during abundant Late Cretaceous magmatism.

[37] The second genetic model, broadly applicable to all Cordilleran back arc contraction belts, envisions that episodes of net contraction between arc and the distal back 
arc region were accommodated by underthrusting of cooler, stronger back arc crust into areas of thermally weakened deeper crust, either in or marginal to the arc [cf. Burchfiel and Davis, 1975; Scholten, 1982; Saleeby, 1999] and/or east of the main arc [cf. Misch, 1960; Miller and Gans, 1989]. Application of this model to the ESTS envisions that the upper part of the arc crust was, at least episodically, sufficiently strong to serve as a buttress against which the upper part of the underthrusting back arc crust was shortened. Depending on the ratio of rock strength (in part, thermally mediated) to compressive stress, the upper crust flanking the arc could respond to arcward underthrusting on a deep-seated contractional detachment in either of two endmember ways, or in a combination of these. (1) If the rock strength to stress ratio in the shallower back arc crust adjacent to the arc is sufficiently high, then the shallower crust remained relatively undeformed but simply translated relatively eastward, either along the basal contractional detachment or along an imbricate splay branching upward from it. This thrust fault could have remained blind or splayed upward to the surface into a fold/thrust belt at some unspecified distance east of the locus of underthrusting. (2) Alternatively, if the rock strength to stress ratio was sufficiently low, then convergence between arc and back arc accompanied by the buttressing effect of the upper arc crust would have been expressed in upper crustal rocks along the east flank of the arc predominantly as arc-normal contraction (local thrusting, folding, ductile flattening), with the intensity of overall deformation being greatest adjacent to the buttress.

[38] We believe that underthrusting, as described above, provides a viable model for evolution of the ESTS. Ducea [2001] used petrogenetic evidence in support of a postulated linkage between a major episode of mid Cretaceous back arc underthrusting beneath the Sierra and the subsequent Late Cretaceous magmatic flare-up that emplaced more than $75 \%$ of the batholith. We hypothesize that episodes of modest underthrusting, of insufficient slip to significantly influence magmatism, may have been frequent and that they best explain the multiple episodes of contractional deformation that gave rise to the ESTS. East vergent thrust faults of Jurassic and Cretaceous age that could have underlain the ESTS and rooted beneath the east edge of the Sierran arc have been postulated to have existed in the Death Valley area [Applegate and Hodges, 1995] and have been mapped in the northeast Mojave Desert. These regions would have been located no farther than $\sim 50 \mathrm{~km}$ east of the ESTS in Mesozoic time [Snow and Wernicke, 2000].

\subsection{Relations Between ESTS and Regional Deformation Events}

[39] Our development of a deformational chronology for the ESTS provides an opportunity to assess the extent to which Mesozoic deformational events that are recognized elsewhere in and adjacent to the continental margin arc were expressed in the ESTS. Much of ESTS deformation correlates with the Nevadan orogeny of the arc and its western host rocks. The Nevadan event was once considered to have been a brief but intense contractional event centered in the northern Sierra Nevada [Schweickert et al., 1984] at $\sim 152 \mathrm{Ma}$. Subsequent studies, however, revealed that (1) important contractional events of Nevadan character begun as early as $\sim 177 \mathrm{Ma}$ in the Klamath Mountains and Sierra Foothills [Saleeby and Busby-Spera, 1992] and (2) both contraction and left-lateral transpressive structures continued to evolve until at least $114 \mathrm{Ma}$ in the Sierran foothills [Wolf and Saleeby, 1995]. Post-Nevadan contractional and right-transpressive structures developed in Sierran roof pendants during the span $\sim 90 \mathrm{Ma}$ to $\sim 80 \mathrm{Ma}$ [Tobisch et al., 2000; Sharp et al., 2000].

[40] Most ESTS deformation was of Nevadan age, as broadly interpreted, although some deformation of the early interval may be older (Figure 12). The less prominent late interval deformation in the ESTS may in part correlate with the post-Nevadan events noted above. We speculate that episodically through time and irregularly through space, there developed stress-to-rock strength ratios favorable for deformation in and adjacent to the entire Sierran arc. During at least one relatively brief interval, $\sim 154$ to $\sim 148 \mathrm{Ma}$, contractional deformation may have occurred across the entire width of the arc at about the same time, as reflected by (1) the culminating thrusting event of the middle interval in the ESTS, (2) possible thrust faulting in eastern Sierra pendants [Tobisch et al., 2000], and (3) significant deformation in the western Sierran foothills [Wolf and Saleeby, 1995]. Left-transpressive components of this Late Jurassic event that are evident in the Sierran foothills [Wolf and Saleeby, 1995] may also be expressed in the ESTS as the minor left-lateral shear zone in the southern Inyo Mountains (Table 2, location 3) and by minor sinistral shear accompanying the emplacement of Independence dikes [Carl et al., 1998].

\section{Conclusions}

[41] The following points summarize our principal conclusions:

[42] 1. Although the ESTS may have accommodated as little as $\sim 9.3 \mathrm{~km}$ of arc-normal contraction, it nonetheless contains an unusually rich record of deformational chronology that reveals that eastern wall rocks of the evolving arc were being deformed over a span of at least 48 m.y. of Mesozoic time, beginning sometime between deposition of early Middle Triassic strata and emplacement of early Middle Jurassic plutons. Although similar contractional structures on strike to the north are as old as Late Triassic, our data permit the interpretation that most contraction in the ESTS occurred between late Early and Late Jurassic time, consistent with observations throughout the SierranKlamath magmatic arc and its host rocks [Saleeby and Busby-Spera, 1992].

[43] 2. The ESTS is one segment of a belt of partly coeval, generally east to southeast vergent contractional structures, including the Luning-Fencemaker belt of western Nevada, that was active along the immediate east margin of the Sierran magmatic arc during middle to late Mesozoic time. Differences in deformational style and kinematics among the different segments may reflect, among other 
possibilities, the effects of very different predeformational geology and/or the existence of local, and perhaps temporary, restraining bends in the obliquely convergent plate boundary.

[44] 3. The spatial and temporal proximity of deformation in the ESTS and magmatism in the Sierran arc leads us to infer a genetic connection between these two phenomena, mediated substantially by thermally controlled rock strength that changed through time, with lateral distance from the arc, and with crustal level. We postulate that convergence between the arc and back arc was accommodated at deep levels by episodic westward underthrusting of relatively cooler, hence stronger, back arc crust into the thermally weakened roots of the arc. The higher, cooler, and hence stronger, levels of the arc, containing abundant massive granitic rock, served as a buttress against which the upper part of the back arc crust, including the ESTS, was shortened and deformed.

[45] 4. Compressional stress oblique to the arc reached into the eastern flank of the arc and at times was sufficiently strong to create arc-parallel lateral shear zones observable in outcrop. Such shear zones in the southern Inyo Mountains can be traced $<1 \mathrm{~km}$ and accommodated limited left slip between $161 \mathrm{Ma}$ and $140 \mathrm{Ma}$ followed by minor right-sense shearing after $140 \mathrm{Ma}$, perhaps in concert with prominent right-lateral shearing in the Panamint Range at $\sim 60 \mathrm{Ma}$ [Andrew, 2002]. Arc-parallel shearing of these ages and senses corresponds well with inferred plate convergence vectors and with resulting arc-parallel shear zones within and/or west of the arc.

[46] 5. The most prominent contractional event in the evolution of the ESTS for which we have good temporal control was the southwest tilting and subsequent thrusting that may have extended the full length of the belt and that occurred within a brief interval at $\sim 150 \mathrm{Ma} \pm 3$. This was a time of left-oblique plate convergence, and this event falls within a time window when contractional to locally left transpressive deformation was occurring in the Klamath Mountains, Sierran foothills, eastern Sierran roof pendant strata, and as far east as eastern Nevada. In terms of regional extent if not total amount of contraction, this episode may have been the most prominent one in the Mesozoic evolution of the arc and its environs.

[47] 6. The development in the southern Inyo Mountains of numerous brittle conjugate strike-slip faults accommodating minor contraction oriented $\sim \mathrm{N} 45^{\circ} \mathrm{E}$, apparently marks the last episode of contraction in the ESTS. These faults may be coeval with similarly oriented microfaults in the Sierra Nevada that were active at $\sim 79 \pm 3 \mathrm{Ma}$. Their development may be the expression of two important regional changes. (1) The orientation of regional principal stresses clearly changed, probably in part owing to changing Late Cretaceous subduction kinematics. (2) Crust in the ESTS displayed increasingly brittle behavior, perhaps caused by the cessation of arc magmatism at $\sim 80$ Ma.

[48] Acknowledgments. Joe Andrew, Conrad Carrle, Mike Defrisco, Rachel Gulliver, Brooks Hanson, Sven Morgan, Scott Paterson, Jason Saleeby, Cal Stevens, Paul Stone, Tim Welch, Rich Whitmarsh, and Sandra Wyld generously shared information and insights regarding eastern California and western Nevada geology. Sharon Stern and Jonathan Linn assisted with TIMS geochronology. Randy Van Schmus (KU) and Mark Fanning (ANU) provided the data and interpretation for SHRIMP geochronology. Financial support for fieldwork was provided to Dunne by CSUN Faculty Research Grants and by the CSUN Department of Geological Sciences. Support for radiometric dating work was provided by NSF grants EAR-9204703 to G. C. Dunne, NSF grant EAR-9205096 to J. D. Walker, and by a grant to J. D. Walker from the Petroleum Research Fund, administered by the American Chemical Society. We thank Rachel Gulliver, Cathy Busby, Mike Wells, Mihai Ducea, and Art Sylvester for reviews of the manuscript. Stereogram software was provided by Rich Allmendinger.

\section{References}

Andrew, J. E. (2002), The Mesozoic and Tertiary tectonic history of the Panamint Range and Quail Mountains, California, Ph.D. dissertation, 154 pp., Univ. of Kansas, Lawrence.

Applegate, J. D., and K. V. Hodges (1995), Mesozoic and Cenozoic extension recorded by metamorphic rocks in the Funeral Mountains, California, Geol. Soc. Am. Bull., 107, 1063-1076.

Barton, M. D., D. A. Battles, G. A. Bebout, R. C. Capo, J. N. Christensen, S. R. Davis, R. B. Hanson, C. J. Michelsen, and H. E. Trim (1988), Mesozoic contact metamorphism in the western United States, in Metamorphism and Crustal Evolution of the Western United States, Rubey Volume 7, edited by W. G. Ernst, pp. 110-178, Prentice Hall, Old Tappan, N. J.

Boettcher, S., and J. D. Walker (1993), Geologic evolution of the Iron Mountain area, central Mojave Desert, California, Tectonics, 12, 373-386.

Burchfiel, B. C., and G. A. Davis (1975), Nature and controls of Cordilleran orogenesis, western United States: Extensions of an earlier synthesis, $\mathrm{Am}$. J. Sci., 275-A, 363-396.

Carl, B. S., A. F. Glazner, J. M. Bartley, D. A. Dinter, and D. S. Coleman (1998), Independence dikes and mafic rocks in the eastern Sierra, in Geological Society of America Cordilleran Section 1998 Field Trip Guidebook, edited by R. Behl, 26 pp., Calif. State Univ., Long Beach.
Chen, J., and J. G. Moore (1982), Uranium-lead isotopic ages from the Sierra Nevada batholith, California, J. Geophys. Res., 87, 4761-4784.

Coleman, D. S., S. Briggs, A. F. Glazner, and C. J. Northrup (2003), Timing of plutonism and deformation in the White Mountains of eastern California, Geol. Soc. Am. Bull., 115, 48-57.

Corbett, K. P., C. T. Wrucke, and C. A. Nelson (1988), Structure and tectonic history of the Last Chance thrust system, Inyo Mountains and Last Chance Range, California, in This Extended Land: Geological Journeys in the Southern Basin and Range, Geological Society of America Cordilleran Section Field Trip Guidebook, edited by D. L. Weide and M. L. Faber, pp. 269-292, Dep. of Geosci., Univ. of Nev., Las Vegas.

Davis, G. A., and B. C. Burchfiel (1973), Garlock fault: An intracontinental transform structure, southern California, Geol. Soc. Am. Bull., 84, 1407-1422.

Ducea, M. (2001), The California arc: Thick granitic batholiths, eclogitic residues, lithospheric-scale thrusting, and magmatic flare-ups, GSA Today, 11, 4-10

Dunne, G. C. (1986), Mesozoic evolution of the southern Inyo Mountains, Darwin Plateau, and Argus and Slate Ranges, in Geological Soc. of America (Cordilleran Section) Field Trip Guidebook and Volume, Trips 2 and 14, compiled by G. C. Dunne, pp. 3-22, Dep. of Geol., Calif. State Univ., Los Angeles.
Dunne, G. C. (2001), Late Cretaceous termination of deformation in the East Sierran Thrust System, eastcentral California, Geol. Soc. Am. Abstr. Programs, $33,38$.

Dunne, G. C. (2003), Geologic map of the East Sierran thrust system, online map, DOI:10.1130/2003dunne-eastsierran, Geol. Soc. of Am., Boulder, Colo.

Dunne, G. C., and J. D. Walker (1993), Age of Jurassic volcanism and tectonism, southern Owens Valley region, east-central California, Geol. Soc. Am. Bull., $105,1223-1230$.

Dunne, G. C., T. P. Garvey, M. Oborne, D. Schneidereit, A. E. Fritsche, and J. D. Walker (1998), Geology of the Inyo Mountains Volcanic Complex: Implications for Jurassic paleogeography of the Sierran magmatic arc in eastern California, Geol. Soc. Am. Bull., 110, $1376-1397$.

Elison, M., and R. Speed (1989), Structural development during flysch basin collapse: The Fencemaker allochthon, East Range, Nevada, J. Struct. Geol., $11,523-538$.

Gulliver, R. M. (1976), Structural analysis of Paleozoic rocks in the Talc City Hills, Inyo County, California, M.S. thesis, 105 pp., Univ. of Calif., Santa Barbara.

Hansen, E. (1971), Strain Facies, 207 pp., SpringerVerlag, New York.

Hanson, R. B., J. B. Saleeby, and D. G. Fates (1987) Age and tectonic setting of Mesozoic metavolcanic 
and metasedimentary rocks, northern White Mountains, California, Geology, 15, 1074-1078.

Hanson, R. E., G. H. Girty, M. S. Girty, U. S. Hargrove, D. S. Harwood, M. J. Kulow, K. L. Mielke, S. E. Phillipson, R. A. Schweickert, and J. H. Templeton (1996), Paleozoic and Mesozoic arc rocks in the northern Sierra terrane, in The Northern Sierra Terrane and Associated Mesozoic Magmatic Units: Implications for the Tectonic History of the Western Cordillera, Book 81, edited by G. H. Girty et al. pp. 25-56, Pac. Sect., Soc. for Sediment. Geol., Fullerton, Calif.

Miller, E. L., and P. B. Gans (1989), Cretaceous crustal structure and metamorphism in the hinterland of the Sevier thrust belt, western U.S. Cordillera, Geology, 17, 59-62.

Misch, P. (1960), Regional structural reconnaissance in central-northeast Nevada and some adjacent areas: Observations and interpretations, in Eleventh Annual Field Conference Guidebook, Intermountain Assoc. of Pet. Geol., Salt Lake City.

Moore, S. C. (1976), Geology and thrust fault tectonics of parts of the Argus and Slate Ranges, Inyo County, California, Ph.D. thesis, 127 pp., Univ. of Wash., Seattle.

Morgan, S. S., and R. D. Law (1998), An overview of Paleozoic-Mesozoic structures developed in the central White-Inyo Range, eastern California, in Integrated Earth and Environmental Evolution of the Southwestern United States, edited by W. G. Ernst and C. A. Nelson, pp. 161-174, Bellwether, Columbia, Md.

Paterson, S. R., and R. B. Miller (1998), Magma emplacement during arc-perpendicular shortening: An example from the Cascades crystalline core, Washington, Tectonics, 17, 571-586.

Oldow, J. S. (1984), Evolution of a late Mesozoic backarc fold and thrust belt, northwestern Great Basin, USA, Tectonophysics, 102, 245-274.

Renne, P. R., S. Mudd, J. Gatdula, and I. S. E. Carmichael (1999), Age of the Benton Range dike swarm revisited, Geol. Soc. Am. Abstr. Programs, 31, A-87.

Saleeby, J. B. (1999), On some aspects of the geology of the Sierra Nevada, in Classic Cordilleran Concepts: A View From California, edited by E. M. Moores, D. Sloan, and D. L. Stout, Spec. Pap. Geol. Soc. Am., 338, 173-184.

Saleeby, J. B., and C. Busby-Spera (1992), Early Mesozoic tectonic evolution of the western U. S Cordillera, in The Geology of North America, vol. G3, The Cordilleran Orogen: Conterminous $U$. S., edited by B. C. Burchfiel, P. W. Lipman, and M. L. Zoback, pp. 107-168, Geol. Soc. of Am., Boulder, Colo.

Scholten, R. (1982), Continental subduction in the northern Rockies: A model for back-arc thrusting in the western Cordillera, in Geologic Studies of the Cordilleran Thrust Belt, edited by R. B. Powers, pp. 123-136, Rocky Mt. Assoc. of Geol., Denver, Colo.

Schweickert, R. A., and M. M. Lahren (1990), Speculative reconstruction of a major early Cretaceous dextral fault zone in the Sierra Nevada: Implications for Paleozoic and Mesozoic orogenesis in the western United States, Tectonics, 9, 1609-1629.

Schweickert, R. A., and M. M. Lahren (1993), Tectonics of the east-central Sierra Nevada-Saddlebag
Lake and northern Ritter Range Pendants, in Crustal Evolution of the Great Basin and the Sierra Nevada, Geological Society of America Cordilleran/Rocky Mountains Section Guidebook, edited by M. M. Lahren, J. H. Trexler Jr., and C. Spinosa, pp. 313-352, Dep. of Geol. Sci., Univ. of Nev., Reno.

Schweickert, R. A., and M. M. Lahren (1999), Triassic caldera at Tioga Pass, Yosemite National Park, California: Structural relationships and significance, Geol. Soc. Am. Bull, 111, 1714-1722.

Schweickert, R. A., N. L. Bogen, G. A. Girty, R. E. Hanson, and C. Merguerian (1984), Timing and structural expression of the Nevadan orogeny, Sierra Nevada, California, Geol. Soc. Am. Bull., 95 , 967-979.

Sharp, W. D., O. T. Tobisch, and P. R. Renne (2000), Development of Cretaceous transpressional cleavage synchronous with batholith emplacement, central Sierra Nevada, California, Geol. Soc. Bull. $112,1059-1066$

Smith, G. I., B. W. Troxel, C. H. Gray Jr., and R. von Huene (1968), Geologic reconnaissance of the Slate Range, San Bernardino and Inyo Counties, Califor nia, Calif. Div. Mines Geol. Spec. Rep., 96, 33 pp.

Snow, J. K. (1992), Large-magnitude Permian shortening and continental-margin tectonics in the southern Cordillera, Geol. Soc. Am. Bull., 104, 80-105.

Snow, J. K., and B. Wernicke (2000), Cenozoic tectonism in the central Basin and Range: Magnitude, rate, and distribution of upper crustal strain, $A m$. J. Sci., 300, 659-719.

Speed, R., M. W. Elison, and F. R. Heck (1988), Phanerozoic tectonic evolution of the Great Basin, in Metamorphism and Crustal Evolution of the Western United States, Rubey Volume 7, edited by W. G. Ernst, pp. 572-605, Prentice Hall, Old Tappan, N. J.

Stern, R. A. (1997), The GSC sensitive high resolution ion microprobe (SHRIMP): analytical techniques of zircon U-Th- $\mathrm{Pb}$ age determinations and performance evaluation, in Radiogenic Age and Isotop Studies: Report 10, Curr. Res. Geol. Surv. Can. 1997-F, 1-31.

Stevens, C. H., and P. Stone (1988), Early Permian thrust faults in east-central California, Geol. Soc Am. Bull., 100, 552-562.

Stevens, C. H., P. Stone, G. C. Dunne, D. C. Greene, J. D. Walker, and B. J. Swanson (1997), Paleozoic and Mesozoic evolution of east-central California, Int. Geol. Rev, 39, 788-829.

Stewart, J. H. (1985), East-trending dextral faults in the western Great Basin: An explanation for anomalous trends in pre-Cenozoic strata and Cenozoic faults, Tectonics, 4, 547-564.

Stone, P., G. C. Dunne, C. H. Stevens, and R. M. Gulliver (1989), Geologic map of Paleozoic an Mesozoic rocks in parts of the Darwin and adjacent quadrangles, Inyo County, California, U.S. Geol. Surv. Misc. Invest. Map I-932, 2 sheets.

Swanson, B. J. (1996), Structural geology and deformational history of the southern Inyo Mountains east of Keeler, Inyo County, California, M. S. thesis, 125 pp., Calif. State Univ., Northridge.

Taylor, W. J., J. M. Bartley, J. E. Fryxell, J. G. Schmidt, and D. S. Vandervoort (1993), Tectonic style and regional relations of the central Nevada thrust belt, in Crustal Evolution of the Great Basin and Sierra Nevada, edited by M. M. Lahren, J. H. Trexler, and C. Spinosa, pp. 57-96, Mackay Sch. of Mines, Reno, Nev.

Tobisch, O. T., S. R. Paterson, J. B. Saleeby, and E. E. Geary (1989), Nature and timing of deformation in the Foothills terrane, central Sierra Nevada, California: Its bearing on orogenesis, Geol. Soc. Am. Bull., $101,401-413$.

Tobisch, O. T., R. S. Fiske, J. B. Saleeby, E. Holt, and S. S. Sorensen (2000), Steep tilting of metavolcanic rocks by multiple mechanisms, central Sierra Nevada, California, Geol. Soc. Am. Bull., 112, $1043-1058$.

Walker, J. D., M. W. Martin, J. M. Bartley, and D. S. Coleman (1990), Timing and kinematics of deformation in the Cronese Hills, California, and implications for Mesozoic structure of the southwestern Cordillera, Geology, 18, 554-557.

Walker, J. D., B. C. Burchfiel, and G. A. Davis (1995), New age controls on initiation and timing of foreland belt thrusting in the Clark Mountains, southern California, Geol. Soc. Am. Bull., 107, 742-752.

Walker, J. D., M. Martin, and A. F. Glazner (2002), Late Paleozoic to Mesozoic development of the Mojave Desert and environs, in Geologic Evolution of the Mojave Desert and Southwest Basin and Range, edited by A. F. Glazner, J. D. Walker, and A. M. Bartley, Mem. Geol. Soc. Am., 195, 1-18.

Welch, T. C., and G. C. Dunne (1999), Superposed deformations in the White Mtns., Inyo County, Calif., Geol. Soc. Am. Abstr. Programs, 31, 107.

Werner, M. R. (1979), Superposed Mesozoic deformations, southeastern Inyo Mountains, California, M.S. thesis, 69 pp., Calif. State Univ., Northridge.

Williams, I. S. (1998), U-Th-Pb geochronology by ion microprobe, in Application of Microanalytical Tech niques to Understanding Mineralizing Processes, edited by M. A. McKibben, W. C. Shanks III, and W. I. Ridley, Rev. Econ. Geol., 7, 1-35.

Wolf, M. B., and J. B. Saleeby (1995), Late Jurassic dike swarms in the southwestern Sierra Nevada foothills terrane, California: Implications for the Nevadan orogeny and North American plate motion, in Jurassic Magmatism and Tectonics of the North American Cordillera, edited by D. M. Miller and C. Busby, Spec. Pap. Geol. Soc. Am., 299, 203-228.

Wyld, S. J., J. W. Rogers, and J. E. Wright (2001), Structural evolution within the Luning-Fencemaker fold-thrust belt, Nevada: Progression from back-arc basin closure to intra-arc shortening, J. Struct. Geol., 23, 1971-1995.

Zoback, M. L. (1992), First- and second-order patterns of stress in the lithosphere: The world stress map project, J. Geophys. Res., 97, 11,703-11,728.

G. C. Dunne, Department of Geological Sciences, California State University Northridge, Northridge, CA 91330-8266, USA. (george.dunne@csun.edu)

J. D. Walker, Department of Geology, University of Kansas, Lawrence, KS 66045-2124, USA. (jdwalker@ ukans.edu) 